\title{
Retrofit solutions for solid wall dwellings in England: The impact of uncertainty upon the energy performance gap
}

\author{
Constantinos Loucari ${ }^{\mathrm{a}}$, Jonathon Taylor ${ }^{\mathrm{a}}$, Rokia Raslan ${ }^{\mathrm{a}}$, Eleni \\ Oikonomou $^{\mathrm{b}}$, Anna Mavrogianni ${ }^{\mathrm{a}}$
}

a: UCL Institute for Environmental Design and Engineering (IEDE), The Bartlett, Faculty of the Built Environment, University College London (UCL), Central House, 14 Upper Woburn Place, London WC1H 0NN

b: UCL Energy Institute, The Bartlett, Faculty of the Built Environment, University College London (UCL), Central House, 14 Upper Woburn Place, London WC1H 0NN

\section{Corresponding author:}

Constantinos Loucari, Institute for Environmental Design and Engineering (IEDE), The Bartlett, Faculty of the Built Environment, University College London,

London.

Email: constantinos.loucari.13@ucl.ac.uk 


\begin{abstract}
This study seeks to evaluate the impact of uncertainty in the pre-retrofit thermal performance of solid walls of English dwellings on post-retrofit energy use. Five dwelling archetypes, broadly representative of English solid wall properties, were modelled pre- and post-retrofit, under different wall insulation scenarios, using dynamic thermal simulation. Findings indicate that whilst solid wall insulation could result in a significant reduction of space heating demand, uncertainties in the preretrofit solid wall U-value could lead to a gap between the anticipated and actual energy performance. Specifically, results show that if the current $\mathrm{U}$-value assumption of $2.1 \mathrm{~W} / \mathrm{m}^{2} \mathrm{~K}$ is indeed an overestimation of the in-situ U-value of solid walls, then the anticipated carbon savings could be significantly reduced by up to $65 \%$.
\end{abstract}

\title{
Practical Application:
}

The performance gap observed in this study revealed that the actual carbon savings arising from the retrofit of solid wall properties could be significantly lower than predicted. This will not only affect UK Government carbon reduction targets, but it can also result in a lack of confidence amongst stakeholders who may consequently doubt the effectiveness of energy retrofit measures, thus reducing their uptake. Uncertainties regarding solid wall U-values may necessitate the reexamination of the carbon targets set for the retrofit of solid wall dwellings and the exploration of alternative ways to further reduce their carbon emissions, e.g. by specifying higher insulation thicknesses. 


\section{Introduction}

\subsection{Background}

Climate change is the major challenge of the $21^{\text {st }}$ century, with severe global consequences for human health, the environment and the economy (1-3). In 2008, the Climate Change Act made the UK the first country to launch a long-term legally binding framework to reduce carbon emissions by $80 \%$ by 2050 compared to 1990 levels (4). Approximately $30 \%$ of the UK's total energy consumption and $25 \%$ of its carbon emissions can be attributed to domestic buildings (5). Around $78 \%$ of building-related energy use is attributed to space heating (5). Therefore, a reduction in domestic space heating demand could significantly contribute towards the decarbonisation of the housing stock. It is estimated that from the 27 million dwellings in the UK today, approximately $80 \%$ will still be standing by 2050 (5). Consequently, the retrofit of existing dwellings is critical for the UK's carbon reduction target.

Currently, approximately one out of four dwellings in England are of solid wall construction (6). Solid wall dwellings are responsible for $36 \%$ of all the housing stock carbon emissions (7). Approximately $96 \%$ of solid wall properties in Great Britain have no wall insulation (8). In these dwellings, wall areas are thought to account for up to $45 \%$ of the dwelling's total heat loss (9), thus representing an area of significant retrofit potential. Approximately $62 \%$ of solid wall properties were constructed prior to the $1920 \mathrm{~s}$, with the majority of them made of bricks (10). Solid brick walls are thought to have specific heat capacities ranging from $800-900 \mathrm{~J} / \mathrm{Kg} \cdot \mathrm{K}$ (11) and a thermal conductivity ranging from $0.69-1.32 \mathrm{~W} / \mathrm{m} \cdot \mathrm{K}(12)$. According to the Government's Reduced Data Standard Assessment Procedure (RdSAP) for the Energy Rating of Dwellings (13), solid brick walls constructed prior to 1929 are assumed to have a U-value of $2.10 \mathrm{~W} / \mathrm{m}^{2} \mathrm{~K}$.

There are a number of constraints in the retrofit of solid walls. Solid wall properties are considered 'Hard-to-Treat' (HTT) (14), as they can only be insulated internally or externally, a process that is more disruptive, costly and time consuming than cavity wall insulation and, in the 
case of external insulation, may be subject to planning permission. Current UK Building Regulations for existing dwellings suggest an improved wall U-value for retrofitted walls of 0.30 $\mathrm{W} / \mathrm{m}^{2} \mathrm{~K}$ and/or a threshold U-value of $0.70 \mathrm{~W} / \mathrm{m}^{2} \mathrm{~K}(15)$. A comparison between external and internal wall insulation is provided in Table 1.

Table 1. Comparison of internal vs. external wall insulation (16) (17)

\begin{tabular}{lll}
\hline Parameter & Internal Insulation & External Insulation \\
\hline Installation costs & Usually lower & Usually higher \\
\hline External Appearance & Unaffected & Affected \\
\hline Thermal bridging & $\begin{array}{l}\text { Disruptive installation thus higher } \\
\text { risk }\end{array}$ & $\begin{array}{l}\text { Continuous installation thus lower } \\
\text { risk }\end{array}$ \\
\hline Planning permission & Not required & May be required \\
\hline Occupant disturbance & $\begin{array}{l}\text { Occupants may need to temporarily } \\
\text { move out of their home }\end{array}$ & Usually not affecting occupants \\
\hline Risk of interstitial condensation & Higher risk & Lower risk \\
\hline Internal floor area & Reduced & Unaffected \\
\hline U-value & $\begin{array}{l}\text { Restricted by the available } \\
\text { installation space }\end{array}$ & No restriction \\
\hline Internal thermal mass & Compromises exposure & Maintains exposure \\
\hline
\end{tabular}

A potential barrier to the widespread acceptance of energy retrofit is the performance gap that is often observed between the predicted and the actual post-retrofit energy performance of a building. Many previous studies have reported failure to achieve the anticipated post-retrofit performance. In a report analysing the results of 37 domestic retrofits of solid wall properties across the UK that aimed at an $80 \%$ reduction in energy use (18), it was specified that only 3 properties achieved the anticipated savings. Similar observations were reported for newly built dwellings across the UK, reporting measured heat loss through the building fabric of $7-130 \%$ more than the predicted value (19-24). As a result, many homeowners may be questioning whether initial capital costs will be paid back through energy savings within a reasonable time frame. This is likely to put the Government's retrofit plans at risk, since inaccuracies in post-retrofit energy savings may result in a lack of confidence amongst homeowners who may be unwilling to invest in retrofit measures with uncertain benefits. 
There are many potential explanations for the energy performance gap, with the following key sources being identified $(25,26)$ :

a) limitations of the building physics-based model algorithms used to calculate building energy performance;

b) discrepancies between the laboratory and in-situ performance of construction materials;

c) discrepancies arising from human errors in construction;

d) uncertainties in occupant behaviour.

Of the uncertainty sources listed above, b) and c) are related to the designed vs. on-site performance of construction elements, which are further analysed below.

The estimated thermal and energy performance of a building is based on the laboratory performance of different construction elements, such as windows and insulation materials, which is achieved under standard laboratory conditions. However, the laboratory and in-situ behaviour of a construction element can substantially vary since conditions that may affect its thermal performance, such as moisture, temperature and airflow, are transient and often very different insitu (26). Nevertheless, such allowances for the real-world performance of construction elements are not factored in during the modelling process (27).

In particular, discrepancies may arise due to uncertainties surrounding the U-value of solid walls. In-situ measurements revealed very different U-values to the ones calculated under steadystate laboratory conditions. The monitoring of the in-situ performance of 87 solid wall properties in England indicated that the U-value of solid walls varied between $0.64-2.52 \mathrm{~W} / \mathrm{m}^{2} \mathrm{~K}$, with a standard deviation of 0.36 and an average U-value of $1.43 \mathrm{~W} / \mathrm{m}^{2} \mathrm{~K}$ across the sample (28), which is well below the SAP standard assumed value of $2.10 \mathrm{~W} / \mathrm{m}^{2} \mathrm{~K}(29)$. A report prepared by the Society for the Protection of Ancient Buildings (SPAB) (30), reported the findings of a study of 60 solid walls that indicated an average monitored U-value of $1.24 \mathrm{~W} / \mathrm{m}^{2} \mathrm{~K}(30)$. This was attributed to the lack of information on accurate conductivity values for some materials, due to unknown constituents of the wall and wall moisture. Discrepancies between calculated and measured U-values due to moisture 
content were reported in another study conducted by English Heritage (31), where the dry and wet state thermal conductivity values of 18 solid wall properties were examined. The wet thermal conductivity was found to be 1.5-3.0 times greater than the dry value indicating that U-values of solid brick walls are affected by variations in brick moisture content. In another recent study (32), the in-situ measurements of the U-value of a $370 \mathrm{~mm}$ thick solid wall of a semi-detached building were recorded for a period of 15 weeks. Although a theoretical U-value of $1.82 \mathrm{~W} / \mathrm{m}^{2} \mathrm{~K}$ was estimated, in-situ measurements indicated an average U-value of around $1.70 \mathrm{~W} / \mathrm{m}^{2} \mathrm{~K}$.

Discrepancies in solid wall U-values may also arise from thermal bridging (33). This may lead to locally different U-values, which would significantly affect the overall wall U-value and, therefore, the anticipated energy savings. The document BR443 'Conventions for U-value Calculations' (34) determines the means for calculating U-values required in Building Regulations Approved Documents L1B and L2B, using the BS EN ISO 6946:1997 standard (35). This standard is based on the use of cavity wall dwellings of known materials and, in many cases, is proven to be inappropriate for the U-value calculation of some existing solid walls $(28,30)$. This standard is used either directly or indirectly by all certifications, technical literature and other Implicit Guidance ${ }^{1}$ for the assessment of existing solid wall U-values and the estimation of potential energy savings from retrofit of solid walls (33).

Discrepancies may also arise from actions that are the result of error or negligence, such as poor onsite workmanship from builders that may compromise the anticipated performance (36). They may also occur as a result of intent. This usually refers to onsite supply chain issues and time pressure that often lead to specified materials being substituted by other products usually cheaper and of inferior quality (21).

There is a wealth of literature $(18,20-24,28,30,32,37)$ investigating the causes of the energy performance gap in new and retrofitted dwellings, highlighting uncertainties surrounding the U-

\footnotetext{
1 Implicit Guidance refers to information commonly used by contractors that does not originate directly from research or formal guidance, but from other sources that include Building Regulations, certifications, trade literature and other industry documents. It guides designers and contractors to specific retrofit applications.
} 
value of solid walls as one of the key sources for this gap. In a recently published study, Li et al. (38) presented the inconsistencies found in the solid wall U-values between the assumed RdSAP Uvalues and the in-situ measurements of the Energy Saving Trust (EST) Solid Wall Insulation Field Trials (SWIFT). These inconsistencies were then used to assess the impact of variations in the assumed solid wall U-values upon the energy consumption of the English housing stock. Using a stock model based on the Building Research Establishment's Domestic Energy Model (BREDEM) (39), it was predicted that changing the U-value from the standard value to $1.3 \mathrm{~W} / \mathrm{m}^{2} \mathrm{~K}$ would lead to $16 \%$ decrease in the mean predicted annual heating demand which could significantly reduce the carbon savings achievable from solid wall insulation (38).

There has, however, been very little research to date indicating how these inconsistencies will affect the energy performance of different dwelling types after solid wall insulation is applied, thus evaluating the impact of these inconsistencies upon the anticipated carbon savings and their further complications on the UK's housing retrofit targets.

\subsection{Project aim and objectives}

This study seeks to build on previous studies (38) and further assess the impact of uncertainties associated with the thermal performance of solid walls on the anticipated energy use and carbon emissions of retrofitted solid wall dwellings, and potential consequences for the UK housing retrofit targets. The aims of this study will be realised through the following objectives:

- to implement dynamic thermal simulation to model a set of solid wall dwellings, broadly representative of the English housing stock, modelling a) different types of wall insulation in order to determine the effectiveness of each type upon energy consumption of the different housing archetypes and b) different insulation levels in order to assess the relationship between insulation thickness and space heating energy savings; 
- To use regression analysis to determine how the relationship between indoor and outdoor environment is affected by different external wall U-values;

- To use sensitivity analysis to determine the impact of uncertainties in the pre-retrofit solid wall U-value upon the energy performance gap.

\section{Methods}

To explore the impact of solid wall retrofitting on the winter energy performance of the English housing stock, four initial steps were taken:

a) a number of existing English dwelling archetypes, their construction details and occupancy patterns for modelling were specified;

b) an appropriate weather file for testing the dwellings was selected;

c) the insulation scenarios to be tested were determined;

d) a fuel intensity factor for translating energy demand to carbon emissions was established.

The simulations were carried out for 15 unique combinations of five different dwelling geometries and three different insulation scenarios. The following steps define the process for assessing a) the impact of the different insulation scenarios upon the energy use of different housing archetypes and b) the impact of modelling uncertainties upon the estimated energy and carbon savings:

1. the energy savings as a result of different insulation scenarios and the associated carbon savings were estimated for each archetype;

2. simple linear regression analysis was performed to assess the relationship between indoor heating demand and external temperatures for different external wall U-values;

3. the inputs and the range of their variants to be used in the sensitivity analysis were determined;

4. simple differential sensitivity analysis was applied to determine the impact of modelling uncertainties on the predicted energy and carbon savings. 
The modelling and dynamic thermal simulations were performed using EDSL-TAS (v. 9.3.1), a widely used and validated dynamic thermal simulation software tool (40). Whilst it is common practice to use steady-state models, such as BREDEM (39), to produce estimates of annual energy use in UK dwellings, this research was part of a larger study that also included a summertime overheating assessment which required a dynamic model. However, many of the input assumptions made in the model development are based on RdSAP values (13), as explained in section 2.2 and Table 4.

\subsection{Dwelling archetypes}

Five different dwelling archetypes were selected for this study as shown in Figure 1; a bungalow, a detached, a semi-detached, an end-terrace and a mid-terrace house, developed using methods described elsewhere (41). These were developed to be broadly representative of the English housing stock as shown in Table 2. According to the English Housing Survey (EHS), dwellings of these types are in their majority owner occupied. Owner occupied properties are the main target of Government retrofit schemes such as the Green Deal (42). These archetypes were modelled with solid walls, meaning that they were assumed to be built prior to 1929 (13). The frequency of each archetype consisting of solid wall properties among the English housing stock is illustrated in Table 3. 


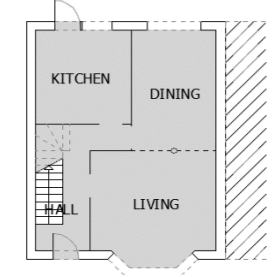

Ground Floo

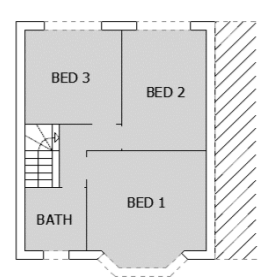

First Floor

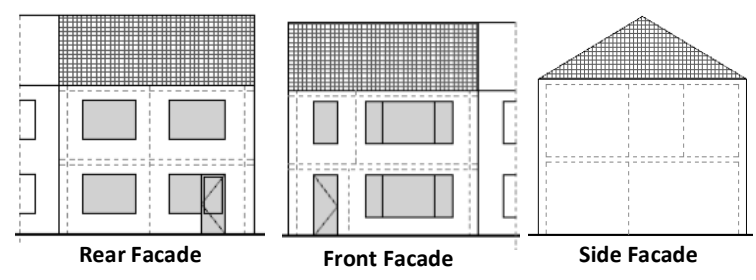

a) End-Terrace

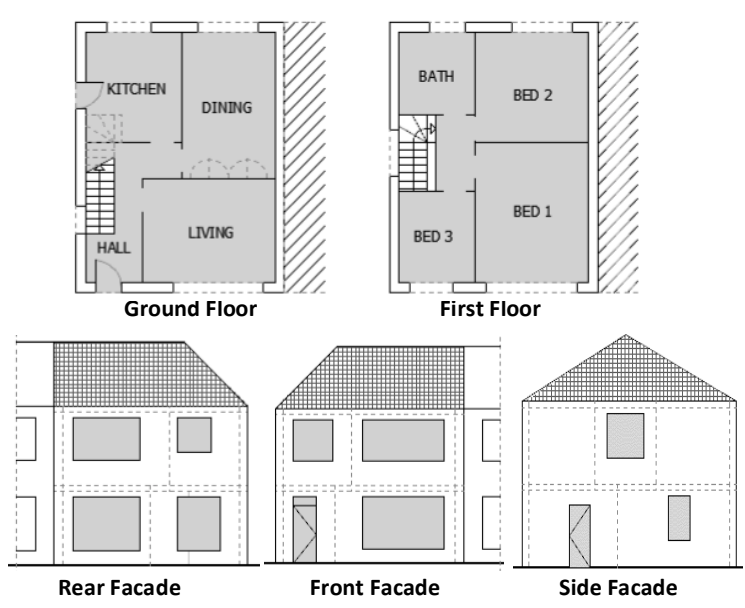

c) Semi-Detached

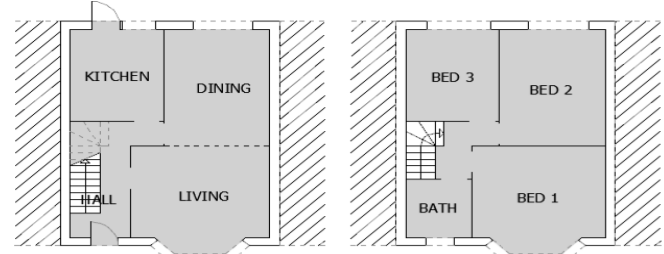

Ground Floor

First Floor

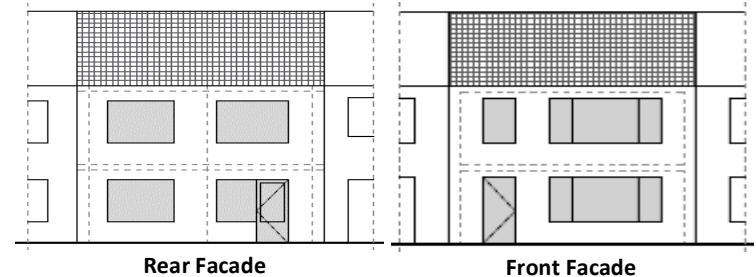

b) Mid-Terrace
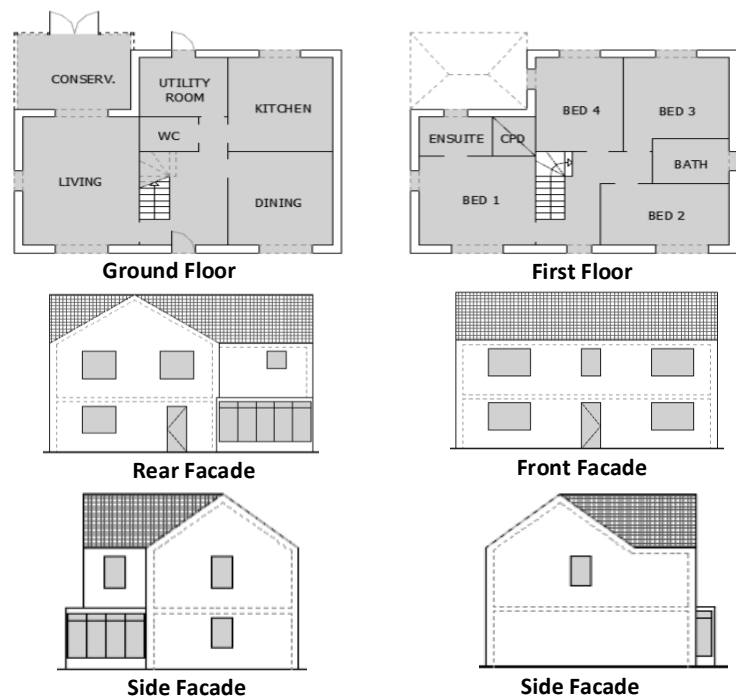

Side Facade

d) Detached

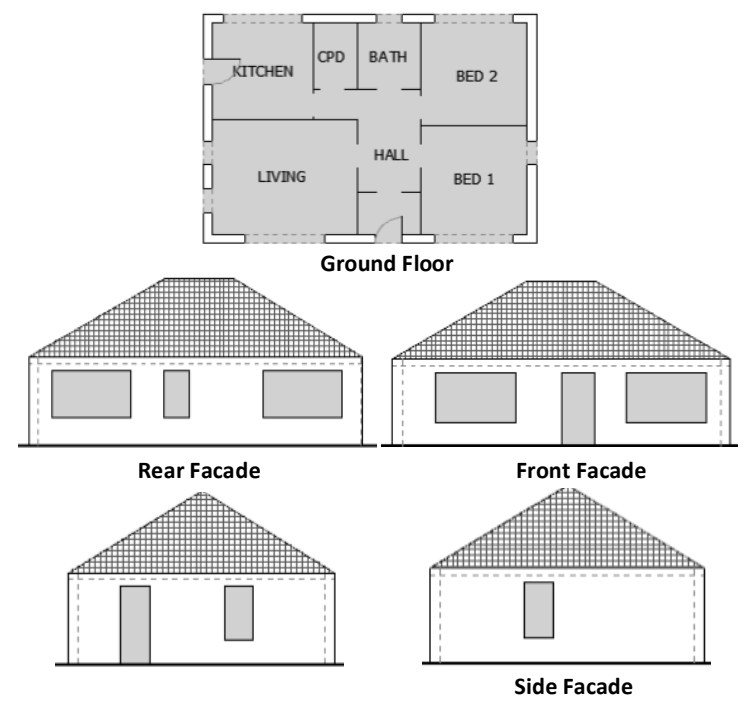

e) Bungalow

Figure 1. The five different archetypes analysed in this study a) End-Terrace, b) Mid-Terrace, c) Semi-Detached, d) Detached, e) Bungalow 
Table 2. Frequency of the five different archetypes to be tested across the English housing stock (6)

\begin{tabular}{lcc}
\hline \multicolumn{1}{c}{ Dwelling type } & Frequency in the English housing stock & Number of dwellings \\
\hline End-terrace & $10 \%$ & $2,300,000$ \\
\hline Mid-terrace & $19 \%$ & $4,370,000$ \\
\hline Semi-detached & $25 \%$ & $5,750,000$ \\
\hline Detached & $15 \%$ & $3,450,000$ \\
\hline Bungalow & $10 \%$ & $2,300,000$ \\
\hline
\end{tabular}

Table 3. The distribution of solid wall dwellings across the English housing stock for the different archetypes analysed in this study (6)

\begin{tabular}{lcc}
\hline \multicolumn{1}{c}{ Type of building } & $\begin{array}{c}\text { Percentage of occurrence in } \\
\text { English housing stock (\%) }\end{array}$ & Number of dwellings \\
\hline End-terrace & 3.8 & 874,000 \\
\hline Mid-terrace & 7.5 & $1,725,000$ \\
\hline Semi-detached & 5.5 & $1,265,000$ \\
\hline Detached & 2.6 & 598,000 \\
\hline Bungalow & 0.6 & 138,000 \\
\hline
\end{tabular}

The building geometries and dimensions of the archetypes were determined through the implementation of statistical analysis on the dimensions of typical English dwellings from the English Housing Survey (EHS) (10) and details of the methods used are presented elsewhere (41). In brief, the internal layout for each archetype was determined using typical floor plans and facades of dwellings with the same age and built form (43-47). The area and orientation of the windows of each dwelling were estimated as a function of the dwelling's floor area, age and built form, using a geometrical model of UK dwellings (48). The construction details for the different construction elements were defined using the EHS (10).

\subsection{Building fabric characteristics}

The same construction details were assumed for all archetypes, since they were all assumed to be of the same age. All construction elements apart from the external walls were assumed to be insulated as part of a whole house retrofit package, to the level required by the current Building 
Regulations (15) under the assumption of an ideal retrofit scenario that includes other potentially invasive retrofits (e.g. floor insulation). The construction details of each construction element are illustrated in Table 4. The glazing area and its orientation for each archetype are illustrated in Table 5. Building ventilation was modelled using an assumed infiltration rate, which was taken as the average for dwellings built prior to $1920(11 \mathrm{ac} / \mathrm{h}$ at $50 \mathrm{~Pa})$ based on Stephen's monitored work (49). The pre-retrofit thermal characteristics of the building fabric were obtained from RdSAP-2009 (13), again by considering the age of the dwellings. A summary of the geometric characteristics of the modelled archetypes is provided in Table 6.

Table 4. Details of the construction elements inputs used in EDSL TAS and resultant U-value for each construction element prior to wall insulation installation.

\section{Construction Element}

\section{External wall}

Internal wall

Loft floor

Suspended wooden floor

Ground floor

\section{Window}

Door

Note 1: Loft, ground floor, doors and glazing were insulated to the level required by current Building Regulations. Note 2: Load bearing components such as floor or loft joists were not required for EDSL TAS thermal simulations

Table 5. Glazing area and orientation for each dwelling

\begin{tabular}{lccccc}
\multicolumn{1}{c}{ Dwelling type } & \multicolumn{5}{c}{ Glazing area $\left(\mathbf{m}^{\mathbf{2}}\right)$} \\
\cline { 2 - 6 } & North & East & West & South & Total \\
\hline End-terrace & 7.9 & - & - & 5.3 & 13.2 \\
\hline Mid-terrace & 7.9 & - & - & 6.7 & 14.6 \\
\hline Semi-detached & 9.6 & - & - & 8.2 & 17.8 \\
\hline Detached & 14.8 & 0.9 & 8.6 & 7.9 & 32.2 \\
\hline Bungalow & 7.4 & 1.1 & 2.2 & 7.0 & 17.7 \\
\hline
\end{tabular}


Table 6. Area of exposed external walls (excluding windows area), exposed surface area, treated floor area and internal volume of each type of dwelling

\begin{tabular}{lccccc}
\hline $\begin{array}{c}\text { Dwelling type } \\
\text { code }\end{array}$ & $\begin{array}{c}\text { Net area of external } \\
\text { walls to be } \\
\left.\text { retrofitted } \mathbf{( m}^{\mathbf{2}}\right)\end{array}$ & $\begin{array}{c}\text { Exposed } \\
\text { surface area } \\
\left(\mathbf{m}^{\mathbf{2}}\right)\end{array}$ & $\begin{array}{c}\text { Floor area } \\
\left.\mathbf{( m}^{\mathbf{2}}\right)\end{array}$ & $\begin{array}{c}\text { Internal } \\
\text { volume }\left(\mathbf{m}^{\mathbf{3}}\right)\end{array}$ & $\begin{array}{c}\text { Exposed surface to } \\
\text { internal volume ratio }\end{array}$ \\
\hline End-terrace & 80 & 138 & 90 & 203 & 1.47 \\
\hline Mid-terrace & 44 & 103 & 90 & 203 & 1.97 \\
\hline Semi-detached & 91 & 159 & 102 & 255 & 1.60 \\
\hline Detached & 141 & 257 & 153 & 341 & 1.33 \\
\hline Bungalow & 64 & 152 & 69 & 154 & 1.01 \\
\hline
\end{tabular}

The insulation scenarios tested are presented in Table 7. The application of $90 \mathrm{~mm}$ of expanded polystyrene (EPS) insulation would decrease the U-value of a solid wall with a preinsulation U-value of $2.10 \mathrm{~W} / \mathrm{m}^{2} \mathrm{~K}$ to $0.30 \mathrm{~W} / \mathrm{m}^{2} \mathrm{~K}$, as required by the $\mathrm{UK}$ Building Regulations (15). It was assumed that the application of insulation would not only affect the wall thermal performance but the building fabric air infiltration as well. There is a great deal of uncertainty in post-retrofit airtightness and infiltration. In this case, post-retrofit infiltration rates were estimated based on the $10 \mathrm{~m}^{3} / \mathrm{h} / \mathrm{m}^{2} @ 50$ Pa best-practice guidance (15), converted to infiltration rate for each building using the 'rule of 20 '(50). The resulting post-retrofit infiltration rates and U-values for each insulation scenario are provided in Table 8.

The models were simulated with their rear façade, which involved the highest glazing ratio for all archetypes, facing west. In this way the dwellings would be exposed to higher solar gains. By maximising solar gains, the dwellings' space heating demand would reduce, enabling the modelling of the worst case scenario in terms of energy savings arising from solid wall insulation.

Table 7. The different insulation scenarios tested

\begin{tabular}{ll}
\hline Insulation Scenario & Intervention \\
\hline $\mathbf{1}$ & No insulation applied to external walls \\
\hline $\mathbf{2 A}$ & Adding $90 \mathrm{~mm}$ of EPS external wall insulation \\
\hline $\mathbf{2 B}$ & Adding $90 \mathrm{~mm}$ of EPS internal wall insulation
\end{tabular}

Note: Insulation density is equal to $30 \mathrm{~kg} / \mathrm{m}^{3}$ and thermal conductivity is equal to $0.033 \mathrm{~W} / \mathrm{mK}(51)$ 
Table 8. Dwellings' infiltration rate and external wall U-value

\begin{tabular}{|c|c|c|c|c|}
\hline \multirow[t]{2}{*}{ Dwelling type } & \multicolumn{2}{|c|}{ External wall U-value (W/m² K) } & \multicolumn{2}{|c|}{$\begin{array}{l}\text { Infiltration rate at 50Pa pressure difference } \\
\text { (ach) }\end{array}$} \\
\hline & Scenario 1 & Scenario 2A,B & Scenario 1 & Scenario 2A,B \\
\hline End terrace & 2.1 & 0.30 & 11.00 & 6.79 \\
\hline Mid-terrace & 2.1 & 0.30 & 11.00 & 5.07 \\
\hline Semi-detached & 2.1 & 0.30 & 11.00 & 6.24 \\
\hline Detached & 2.1 & 0.30 & 11.00 & 7.52 \\
\hline Bungalow & 2.1 & 0.30 & 11.00 & 9.84 \\
\hline
\end{tabular}

Note: Scenario 2A refers to external wall insulation, and scenario $2 \mathrm{~B}$ to internal wall insulation

\subsection{Building systems and fuel intensity factors}

Although the vast majority of English dwellings are served by gas central heating, electric heating was assumed to avoid additional uncertainty imposed by the efficiency of gas boilers. Nevertheless, many of these dwellings will use natural gas, which is characterised by a different carbon factor that will lead to different carbon savings. To estimate the operational carbon emissions, a carbon emission factor of $0.519 \mathrm{~kg} / \mathrm{kWh}$ was used as provided in SAP-2012 (29).

\subsection{External climate}

All simulations were carried out for the London climate. This is because London as illustrated in Table 9 below has the highest solid wall distribution of all the English regions, thus this weather file would characterise the majority of solid properties in England (10). The Chartered Institution of Building Services Engineers' (CIBSE) Test Reference Year (TRY) weather file was used (52) for the calculation of the dwelling annual energy consumption. Additionally, since London is one of the warmest English cities, this represents a 'worst-case' scenario for energy savings. This allows us to see whether retrofit would be a viable option in these 'worst-case' scenarios. 
Table 9. Distribution of different wall types among different English regions

\begin{tabular}{|c|c|c|c|c|c|c|c|c|c|c|}
\hline \multirow{2}{*}{ Region } & \multicolumn{9}{|c|}{ Predominant type of wall structure } & \multirow{2}{*}{$\begin{array}{c}\text { Solid } \\
\text { Walls } \\
\text { Total } \\
\text { Frequency }\end{array}$} \\
\hline & $\begin{array}{c}\text { mixed } \\
\text { types }\end{array}$ & $\begin{array}{l}\text { masonry } \\
\text { cavity }\end{array}$ & $\begin{array}{c}\text { masonry } \\
\text { single } \\
\text { leaf }\end{array}$ & $\begin{array}{l}9 \text { inch } \\
\text { solid }\end{array}$ & $\begin{array}{c}\text { greater } \\
\text { than } 9 \\
\text { inch solid }\end{array}$ & $\begin{array}{l}\text { in situ } \\
\text { concrete }\end{array}$ & $\begin{array}{l}\text { concrete } \\
\text { panels }\end{array}$ & $\begin{array}{l}\text { timber } \\
\text { panels }\end{array}$ & $\begin{array}{l}\text { metal } \\
\text { sheet }\end{array}$ & \\
\hline North East & $6.2 \%$ & $6.7 \%$ & $1.5 \%$ & $2.3 \%$ & $4.5 \%$ & $7.2 \%$ & $4.4 \%$ & $1.7 \%$ & $4.8 \%$ & $8.3 \%$ \\
\hline $\begin{array}{l}\text { Yorkshire } \\
\text { and the } \\
\text { Humber }\end{array}$ & $11.8 \%$ & $12.4 \%$ & $11.9 \%$ & $9.3 \%$ & $17.7 \%$ & $12.0 \%$ & $12.7 \%$ & $2.3 \%$ & $11.9 \%$ & $38.9 \%$ \\
\hline $\begin{array}{l}\text { North } \\
\text { West }\end{array}$ & $14.9 \%$ & $16.3 \%$ & $10.4 \%$ & $10.7 \%$ & $12.2 \%$ & $18.7 \%$ & $10.2 \%$ & $6.8 \%$ & $9.5 \%$ & $33.3 \%$ \\
\hline $\begin{array}{c}\text { East } \\
\text { Midlands }\end{array}$ & $8.1 \%$ & $8.5 \%$ & $11.9 \%$ & $11.6 \%$ & $4.9 \%$ & $13.9 \%$ & $6.8 \%$ & $8.0 \%$ & $7.1 \%$ & $28.4 \%$ \\
\hline $\begin{array}{c}\text { West } \\
\text { Midlands }\end{array}$ & $9.3 \%$ & $9.4 \%$ & $4.5 \%$ & $12.1 \%$ & $4.2 \%$ & $15.8 \%$ & $9.8 \%$ & $10.8 \%$ & $2.4 \%$ & $20.8 \%$ \\
\hline $\begin{array}{l}\text { South } \\
\text { West }\end{array}$ & $10.2 \%$ & $11.1 \%$ & $9.0 \%$ & $3.2 \%$ & $22.8 \%$ & $7.2 \%$ & $15.6 \%$ & $10.2 \%$ & $14.3 \%$ & $35.0 \%$ \\
\hline $\begin{array}{c}\text { East } \\
\text { England }\end{array}$ & $12.7 \%$ & $11.3 \%$ & $9.0 \%$ & $11.6 \%$ & $5.5 \%$ & $5.3 \%$ & $7.3 \%$ & $26.7 \%$ & $11.9 \%$ & $26.1 \%$ \\
\hline South East & $12.1 \%$ & $16.8 \%$ & $23.9 \%$ & $10.3 \%$ & $6.8 \%$ & $8.6 \%$ & $8.8 \%$ & $21.0 \%$ & $16.7 \%$ & $41.0 \%$ \\
\hline London & $14.6 \%$ & $7.5 \%$ & $17.9 \%$ & $29.0 \%$ & $21.4 \%$ & $11.5 \%$ & $24.4 \%$ & $12.5 \%$ & $21.4 \%$ & $68.3 \%$ \\
\hline
\end{tabular}

Note: the types of walls considered as solid walls are a) masonry single leaf, b) 9 inch solid and c) greater than 9 inch solid

\subsection{Occupancy patterns and behaviour}

Existing assumptions on typical occupancy patterns in UK dwellings from a previously published study were applied (53). A family occupancy of five was assumed for dwellings with more than 3-bedrooms and occupancy of four for dwellings with 2-bedrooms. Details regarding the daily occupancy schedule during weekdays are provided in Table 9. Internal heat gains arising from the occupants metabolic rates were calculated using data from CIBSE (54) while standard family occupancy, lights, appliances and window opening schedules were assumed based on various studies (54-61). Internal gains assigned for each zone are illustrated in Table 10. However, it is expected that there will be wide distribution of occupancy patterns across solid wall dwellings over England. Differences in occupancy patterns and indoor temperature preferences will have an immediate impact upon the dwelling's space heat demand. All dwellings were modelled as naturally ventilated, in line with the CIBSE Guide A recommendations (54). 
Table 10. The weekday occupancy schedule for each space. During weekends, the living room is occupied by 2 people between 10:00-12:00 \& 18:00-20:00. Where less than four bedrooms were available, a double occupancy was assumed in more than one bedroom.

\begin{tabular}{|c|c|c|c|c|c|c|c|c|c|c|c|c|c|c|c|c|c|c|c|c|c|c|c|c|}
\hline & $\begin{array}{l}\text { ஜ̊̊. } \\
\stackrel{8}{8}\end{array}$ & 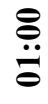 & $\begin{array}{l}\stackrel{\leftrightarrow}{\ddot{\theta}} \\
\text { ه̆ }\end{array}$ & 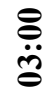 & 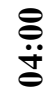 & 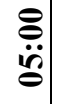 & 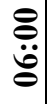 & 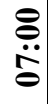 & $\begin{array}{c}\stackrel{8}{\ddot{\theta}} \\
\stackrel{0}{\theta}\end{array}$ & 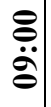 & 茴 & $\begin{array}{l}\stackrel{8}{\stackrel{\theta}{\Xi}} \\
\end{array}$ & 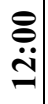 & 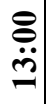 & $\begin{array}{l}\stackrel{8}{\dot{\leftrightarrow}} \\
\dot{ \pm}\end{array}$ & $\begin{array}{l}\stackrel{8}{\leftrightarrow} \\
\ddot{0}\end{array}$ & $\begin{array}{l}\stackrel{0}{0} \\
\ddot{0}\end{array}$ & 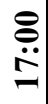 & $\begin{array}{l}\stackrel{8}{\ddot{0}} \\
\stackrel{0}{-}\end{array}$ & $\begin{array}{l}\stackrel{\theta}{\sigma} \\
\ddot{\sigma}\end{array}$ & 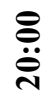 & 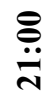 & $\begin{array}{l}\stackrel{\leftrightarrow}{\ddot{~}} \\
\text { ते }\end{array}$ & $\begin{array}{l}\ddot{\ddot{n}} \\
\ddot{\ddot{\nu}}\end{array}$ \\
\hline Kitchen & & & & & & & & & $\mathbf{x}$ & & & & & & & & & & $\mathbf{x}$ & & & & & \\
\hline Bathroom & & & & & & & & $\mathbf{x}$ & $\mathbf{x}$ & $\mathbf{x}$ & & & & & & & & & & & $\mathbf{x}$ & $\mathbf{x}$ & $\mathbf{x}$ & \\
\hline Living Room & & & & & & & & & & & & & & & & & & & $\mathbf{x}$ & $\mathbf{x}$ & $\mathbf{x}$ & & & \\
\hline Bedroom 1 & $\mathbf{x}$ & $\mathbf{x}$ & $\mathbf{x}$ & $\mathbf{x}$ & $\overline{\mathbf{x}}$ & $\bar{x}$ & $\mathbf{x}$ & $\mathbf{x}$ & & & & & & & & & & & & & & & & $\mathbf{x}$ \\
\hline Bedroom 2 & $\mathbf{x}$ & $\mathbf{x}$ & $\mathbf{x}$ & $\mathbf{x}$ & $\mathbf{x}$ & $\mathbf{x}$ & $\mathbf{x}$ & $\mathbf{x}$ & $\mathbf{x}$ & & & & & & & & & & $\mathbf{x}$ & $\mathbf{x}$ & & $\bar{x}$ & $\mathbf{x}$ & $\mathbf{x}$ \\
\hline Bedroom 3 & $\mathbf{x}$ & $\mathbf{x}$ & $\mathbf{x}$ & $\mathbf{x}$ & $\mathbf{x}$ & $\mathbf{x}$ & $\mathbf{x}$ & $\mathbf{x}$ & $\mathbf{x}$ & & & & & & & & & & $\mathbf{x}$ & $\mathbf{x}$ & & $\mathbf{x}$ & $\mathbf{x}$ & $\mathbf{x}$ \\
\hline Bedroom 4 & $\mathbf{x}$ & $\mathbf{x}$ & $\mathbf{x}$ & $\mathbf{x}$ & $\mathbf{x}$ & $\mathbf{x}$ & $\mathbf{x}$ & $\mathbf{x}$ & $\mathbf{x}$ & & & & & & & & & & $\mathbf{x}$ & $\mathbf{x}$ & & $\mathbf{x}$ & $\mathbf{x}$ & $\mathbf{x}$ \\
\hline
\end{tabular}

Table 11. Internal heat gains

\begin{tabular}{|c|c|c|c|}
\hline \multirow[b]{2}{*}{ Type of space } & \multicolumn{3}{|c|}{ Internal (sensible) heat gains } \\
\hline & Occupancy (W) & Equipment (W) & Lights $\left(\mathrm{W} / \mathrm{m}^{2}\right)$ \\
\hline Kitchen & 60 & 70 & 10 \\
\hline Bathroom & 60 & - & 10 \\
\hline Living room & 120 & 150 & 10 \\
\hline Bedroom 1 & 110 & - & 10 \\
\hline Bedroom 2 & 55 & - & 10 \\
\hline Bedroom 3 & 55 & - & 10 \\
\hline Bedroom 4 & 55 & - & 10 \\
\hline
\end{tabular}

\subsection{Statistical analysis}

To assess the impact of uncertainties arising from modelling assumptions, Differential Sensitivity Analysis (DSA) was carried out. DSA is commonly used to examine directly the effect that different input variants will have upon the output (62). Repeated simulations in which one input parameter is changed each time allow the individual effects of all the input variations to be determined. The process in determining individual sensitivities from each input is described in Equation 1:

$\Delta P_{i}=P_{i}-P_{B}$

where $P_{i}$ refers to the predicted output using a modified value of input $i, P_{B}$ refers to the predicted output when using base case inputs and $\Delta P_{i}$ refers to the individual effect of each input variation. 
DSA was carried out to assess the impact of uncertainties upon the dwelling's energy and carbon emissions savings post-retrofit. Variations in the following modelling inputs were tested:

- Solid wall pre-insulation U-value

- Insulation thickness

For the base case, the pre-insulation $\mathrm{U}$-value of the solid wall was set at $2.10 \mathrm{~W} / \mathrm{m}^{2} \mathrm{~K}$ and the thickness of EPS insulation to be added at $90 \mathrm{~mm}$. The $2.10 \mathrm{~W} / \mathrm{m}^{2} \mathrm{~K}$ refers to the solid wall Uvalue specified in RdSAP (13) and the $90 \mathrm{~mm}$ of insulation refers to the thickness of EPS insulation required to drop the $\mathrm{U}$-value of a solid wall to $0.30 \mathrm{~W} / \mathrm{m}^{2} \mathrm{~K}$, as required by the $\mathrm{UK}$ Building Regulations (15). The lower and upper limits of the pre-insulation wall U-value, were obtained using the minimum $\left(0.64 \mathrm{~W} / \mathrm{m}^{2} \mathrm{~K}\right)$ and maximum $\left(2.52 \mathrm{~W} / \mathrm{m}^{2} \mathrm{~K}\right) \mathrm{U}$-values reported in existing insitu measurements (28). The energy savings arising from these U-values were calculated and were subsequently converted to carbon savings. The process followed for this sensitivity analysis is illustrated schematically in Figure 2.

For the insulation thickness the upper value was assumed after considering the U-values of external walls of different Passivhaus dwellings (63). Passivhaus dwellings involve external walls of U-values of $0.10 \mathrm{~W} / \mathrm{m}^{2} \mathrm{~K}$. Thus, an insulation thickness of $310 \mathrm{~mm}$ of EPS, required to drop the solid wall U-value from $2.10 \mathrm{~W} / \mathrm{m}^{2} \mathrm{~K}$ to $0.10 \mathrm{~W} / \mathrm{m}^{2} \mathrm{~K}$ was used. For the lower value, an insulation thickness of $30 \mathrm{~mm}$ of EPS, required to drop the solid walls $\mathrm{U}$-value from $2.10 \mathrm{~W} / \mathrm{m}^{2} \mathrm{~K}$ to 0.70 $\mathrm{W} / \mathrm{m}^{2} \mathrm{~K}$. According to Building Regulations, this represents the threshold U-value that should be achieved from a solid wall retrofit, if a U-value of $0.30 \mathrm{~W} / \mathrm{m}^{2} \mathrm{~K}$ is not technically, functionally or economically feasible to achieve (15). Input variants tested are provided in Table 11.

Additional analysis was carried out to assess a further hypothesis. This hypothesis considered a pre-insulation solid wall U-value of $0.64 \mathrm{~W} / \mathrm{m}^{2} \mathrm{~K}$ and estimated the carbon savings arising if $310 \mathrm{~mm}$ of EPS external insulation were installed. The carbon savings arising from this hypothesis were then compared to the carbon savings estimated using the base-case values. The 
purpose of this analysis was to determine if thicker insulation could recover the 'lost' carbon savings if lower solid wall U-values actually applied. However, it needs to be highlighted here that this is just an indicative comparison due to significant uncertainties stemming mainly from the lack of knowledge about the actual occupant patterns, occupant behaviour and the rebound effect ${ }^{2}$.

Table 12. Base case values and variations tested for the two inputs: a) solid wall pre-insulation U-value, b) insulation thickness. Base case refers to the energy savings estimated by RdSAP, if dwellings are retrofitted according to Building Regulations

\begin{tabular}{|c|c|c|c|}
\hline Perturbed input & $\begin{array}{c}\text { Solid wall pre-retrofit } U \text { - } \\
\text { value }\left(W / \mathbf{m}^{2} K\right)\end{array}$ & $\begin{array}{c}\text { Solid wall added } \\
\text { insulation thickness } \\
(\mathrm{mm})\end{array}$ & $\begin{array}{c}\text { Solid wall post-retrofit } \\
\text { U-value }\left(W / \mathbf{m}^{2} \mathbf{K}\right)\end{array}$ \\
\hline \multirow{3}{*}{$\begin{array}{c}\text { Solid wall pre-retrofit } U \text { - } \\
\text { value }\left(W / \mathbf{m}^{2} K\right)\end{array}$} & 2.10 & \multirow{3}{*}{90} & 0.30 \\
\hline & 0.64 & & 0.23 \\
\hline & 2.52 & & 0.32 \\
\hline \multirow{3}{*}{$\begin{array}{c}\text { Solid wall added } \\
\text { insulation thickness } \\
(\mathrm{mm})\end{array}$} & \multirow{3}{*}{2.10} & 90 & 0.30 \\
\hline & & 30 & 0.70 \\
\hline & & 310 & 0.10 \\
\hline
\end{tabular}

Regression analysis was carried out to assess the correlation between the external temperature, the external walls U-value and heating loads. The analysis was performed using results arising from the external insulation scenario.

\footnotetext{
${ }^{2}$ There is also the 'rebound effect' that refers to post-retrofit changes on the thermal comfort levels that instead of reducing energy demand they use the energy saved to raise indoor temperature, leading to lower energy savings than the ones expected (UKERC 2007).
} 


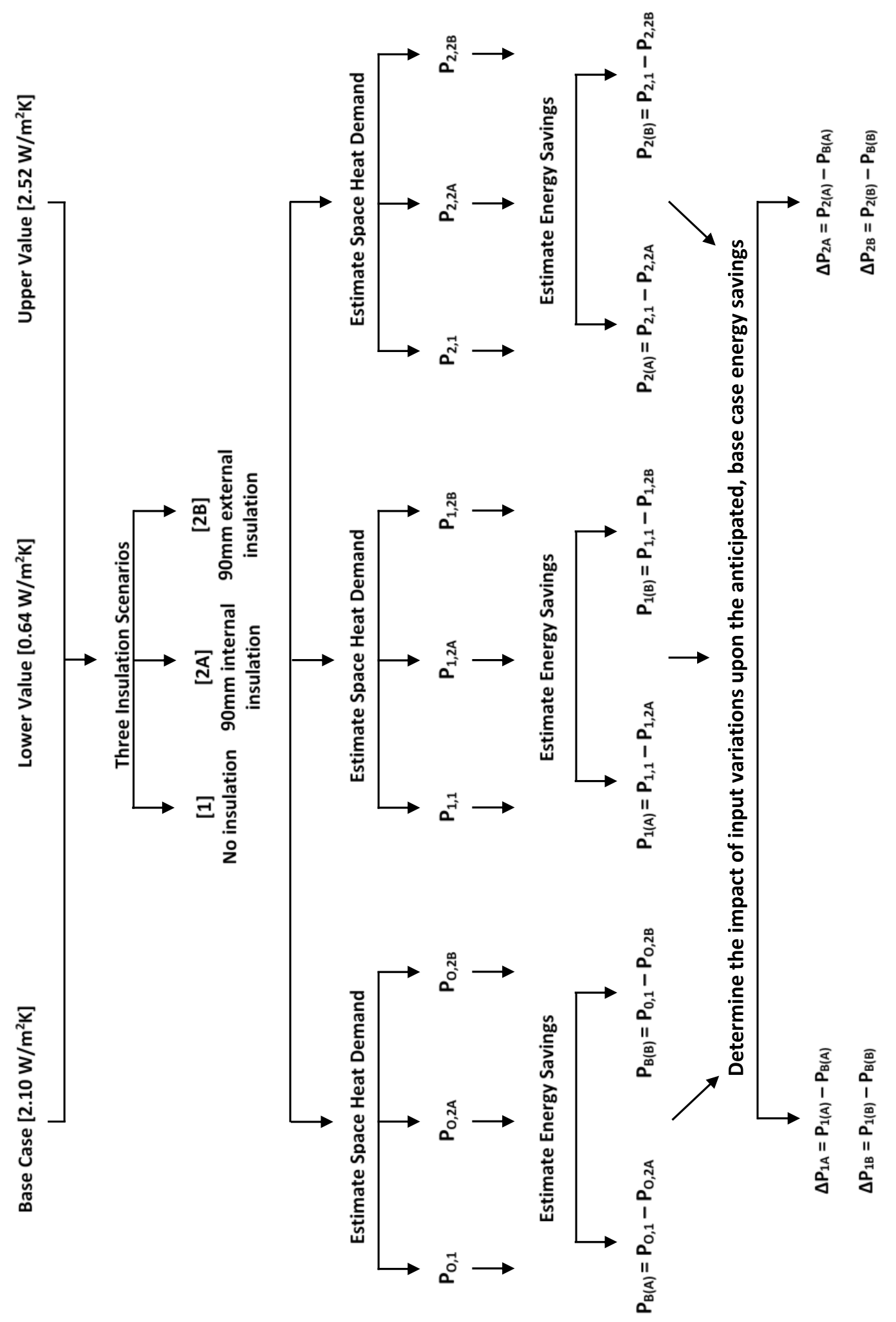

Figure 2. Implementation of the DSA process for the solid wall's pre-insulation U-value 


\section{Results}

\subsection{Modelled thermal performance}

The annual space heat demand was estimated for the pre-insulation (Scenario 1) and the two post-insulation scenarios (Scenarios 2A \&2B) for each dwelling archetype. Caution is advised in the interpretation of absolute values given the level of uncertainty that lies in the assumptions made in this study, however, the relative changes offer valuable insights in the performance of the dwelling pre- and post-retrofit. The installation of insulation, either externally or internally, reduced the annual space heat demand substantially, although internal insulation was found to be slightly more effective. The percentage reduction in space heat demand ranged from $60 \%$ to $66 \%$ when compared to the pre-insulation baseline condition for the external insulation scenario and from $62 \%$ to $68 \%$ for the internal insulation scenario. The absolute energy and carbon savings were affected by the exposed wall surface area of each dwelling. The greatest savings were achieved in the detached house while the lowest in the mid-terrace house, as illustrated in Figure 3.

Figure $4 \mathrm{a}$ shows the energy savings achieved per exposed wall surface area and Figure $4 \mathrm{~b}$ the exposed surface area to volume ratio of each dwelling. It was found that the mid-terrace house achieved the highest energy savings per $\mathrm{m}^{2}$ of insulation applied while the detached and the bungalow the lowest. In addition, it was observed that as the exposed surface area to volume ratio of a dwelling increased, the energy savings arising per $\mathrm{m}^{2}$ of insulation applied decreased. 


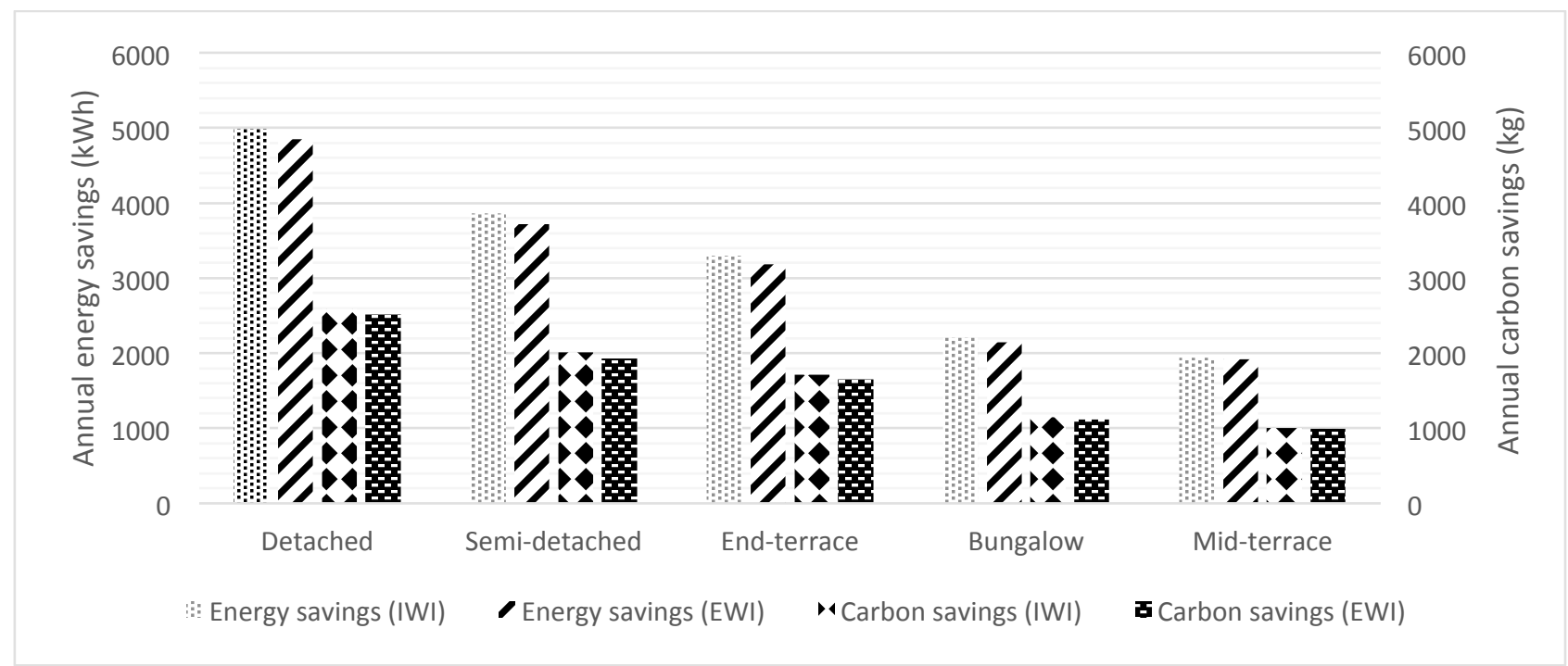

Figure 3. Annual carbon savings expected for each archetype as a result of external wall insulation (EWI) and internal wall insulation (IWI) 


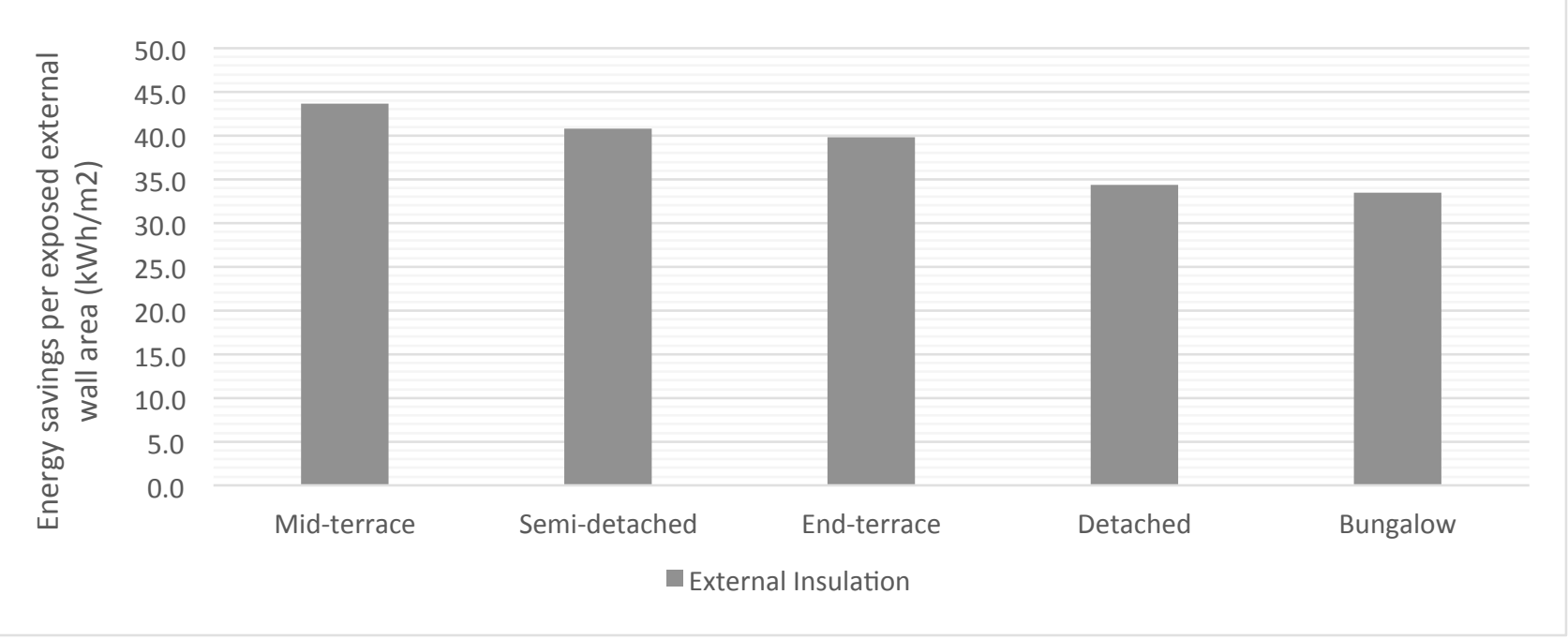

(a)

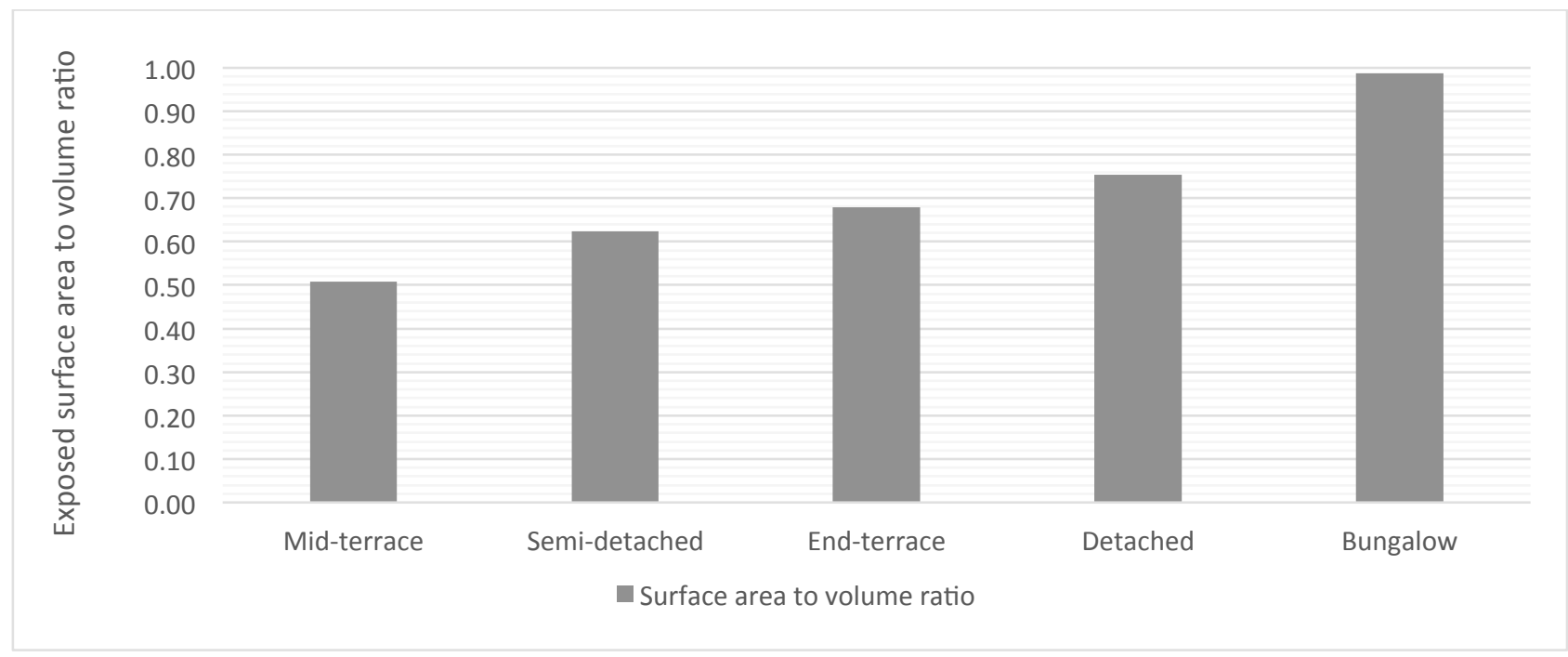

(b)

Figure 4. The relationship between (a) the energy savings produced per $\mathrm{m}^{2}$ exposed wall surface area and (b) the exposed wall surface area-to-volume ratio for each dwelling archetype

\subsection{Differential sensitivity analysis}

The results of the sensitivity analysis for the pre-retrofit wall U-value are illustrated in Figure 5. The graph illustrates how the energy savings anticipated for the base case values could be affected if the pre-insulation U-value of the solid wall is equal to $0.64 \mathrm{~W} / \mathrm{m}^{2} \mathrm{~K}$ or $2.52 \mathrm{~W} / \mathrm{m}^{2} \mathrm{~K}$ instead of $2.10 \mathrm{~W} / \mathrm{m}^{2} \mathrm{~K}$. Energy savings seem to be approximately 3 times more sensitive when the solid wall U-value is equal to $0.64 \mathrm{~W} / \mathrm{m}^{2} \mathrm{~K}$ rather than $2.52 \mathrm{~W} / \mathrm{m}^{2} \mathrm{~K}$. Although the change in absolute energy savings was greater for the detached dwelling and lower for the mid-terrace dwelling, the greatest percentage decrease/increase was observed in the mid-terrace dwelling. 
Consequently, the most sensitive archetype to these changes, as illustrated in Figure 5b was by a small margin the mid-terrace house and the least sensitive the bungalow. It was also observed that the anticipated savings seemed to be slightly (but not significantly) more sensitive for the scenario where insulation was applied externally.

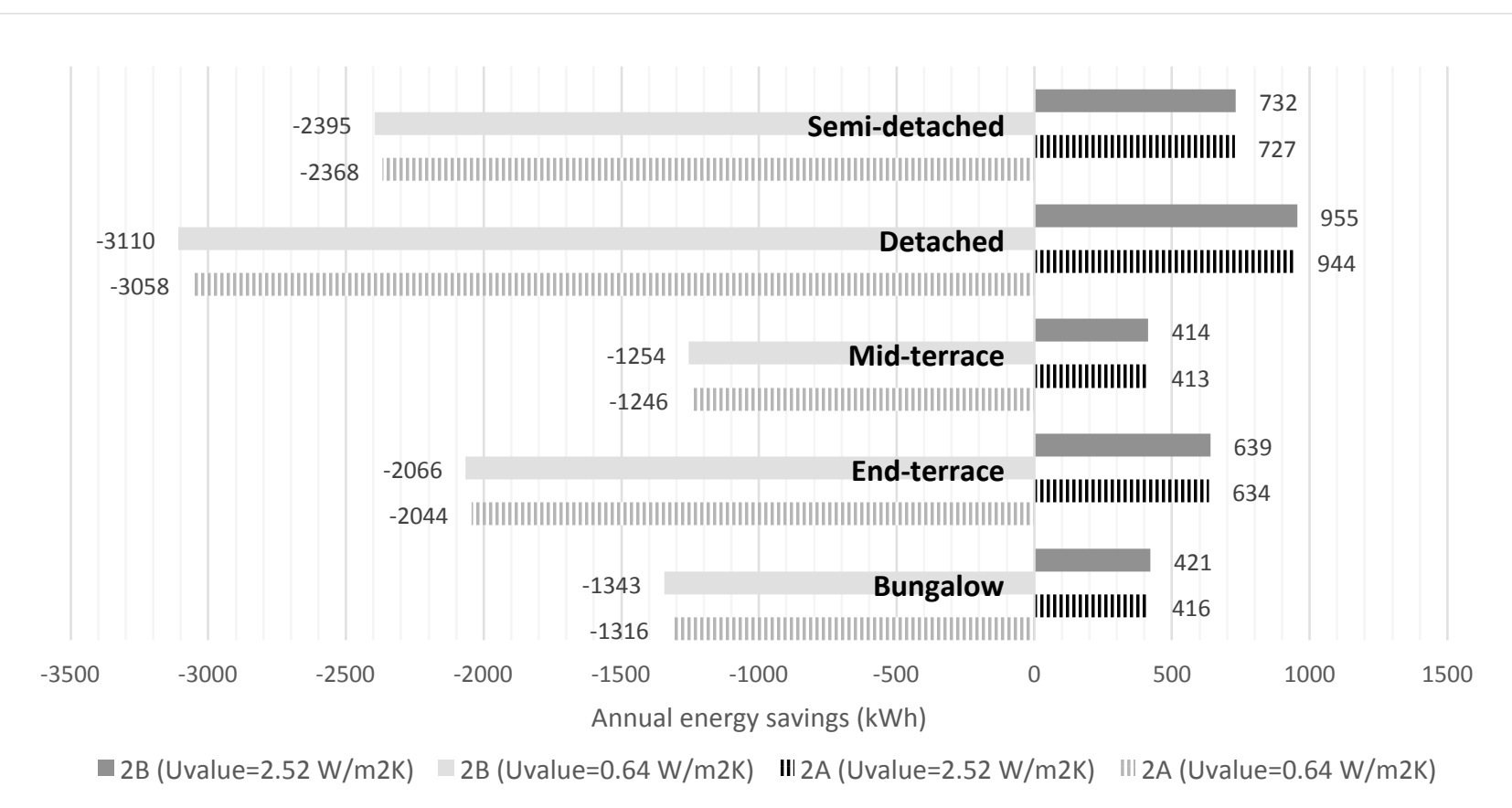

(a)

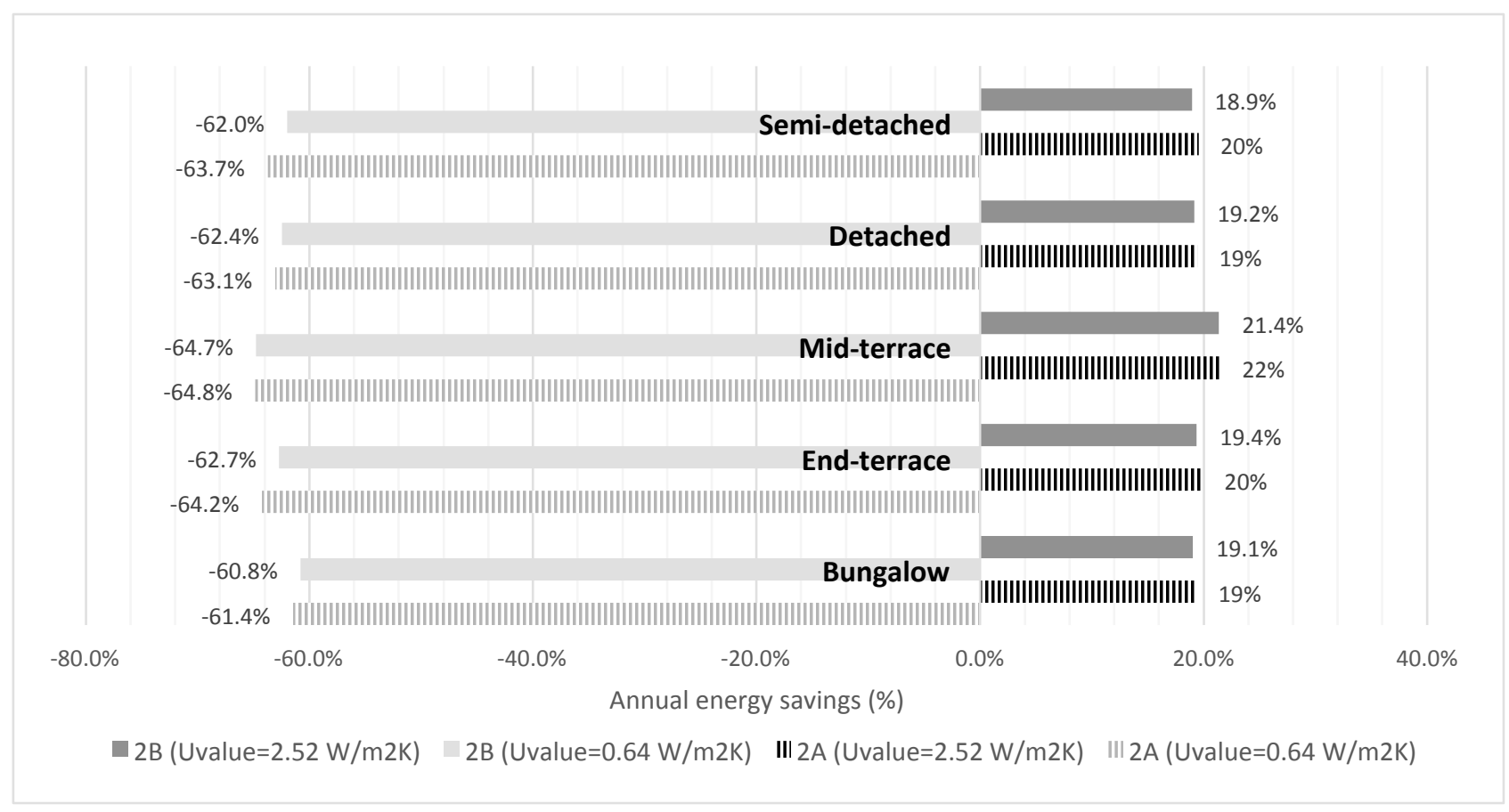

(b)

Figure 5. The impact on energy savings due to external (2A) and internal (2B) wall insulation, if the actual solid wall $\mathrm{U}$-value is lower or higher than the $2.1 \mathrm{~W} / \mathrm{m} 2 \mathrm{~K}$ value assumed for solid walls in the UK. More specifically, results display how the annual energy savings achieved by the addition of $90 \mathrm{~mm}$ of EPS insulation (base case assumption) 
would be affected, if the actual uninsulated solid wall $\mathrm{U}$-value was $0.64 \mathrm{~W} / \mathrm{m} 2 \mathrm{~K}$ or $2.52 \mathrm{~W} / \mathrm{m} 2 \mathrm{~K}$ instead of $2.1 \mathrm{~W} / \mathrm{m} 2 \mathrm{~K}$. Figure (a) illustrates the change in annual energy savings as absolute values in $\mathrm{kWh}$ and Figure (b) as percentage increase or decrease.

The insulation thickness sensitivity analysis results are illustrated in Figure 6. This graph explores how the energy savings could be affected if the thickness of the insulation added was reduced from $90 \mathrm{~mm}$ to $30 \mathrm{~mm}$ or increased to $310 \mathrm{~mm}$. It is indicated that savings are more sensitive to the reduced rather than to the increased insulation thickness, even if the change in the insulation thickness was less for decreased thickness $(60 \mathrm{~mm})$, than the increased in thickness $(220 \mathrm{~mm})$. The dwelling that was found to be the most sensitive to changes in the insulation thickness was the detached house and the least sensitive the mid-terrace house. As with the U-value sensitivity analysis, it was observed that the anticipated savings seemed to be slightly more sensitive where insulation was applied externally.

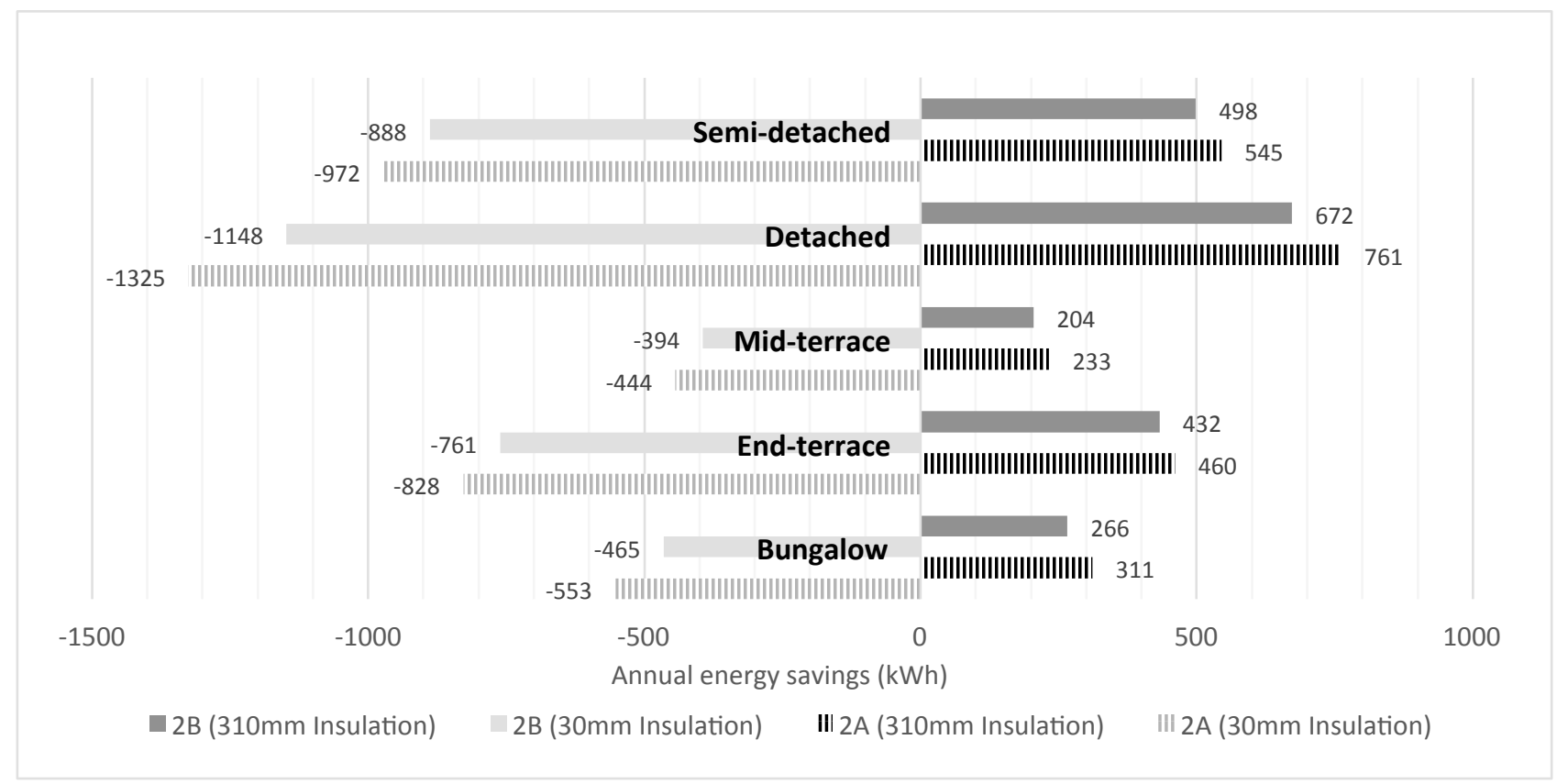

(a) 


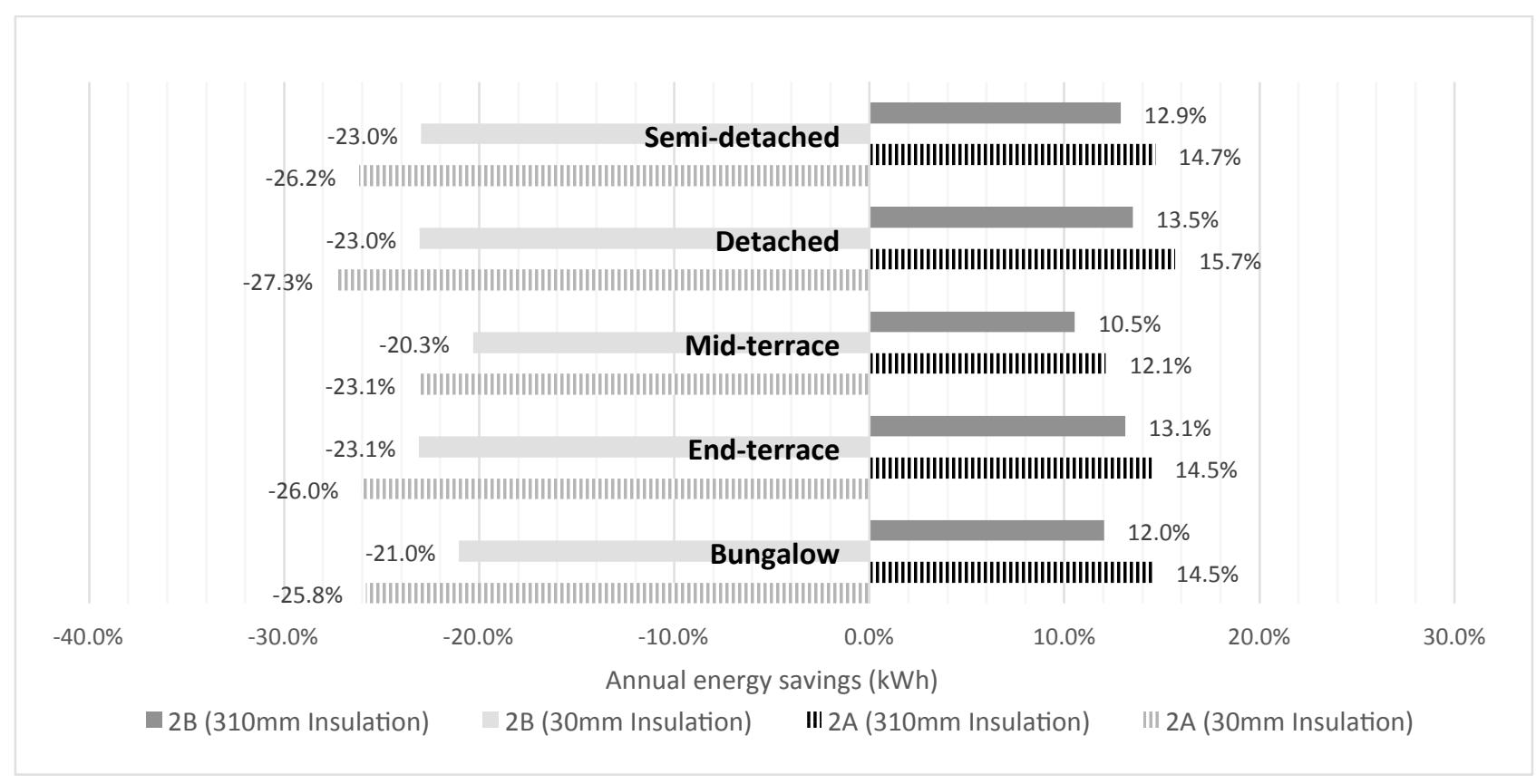

(b)

Figure 6. The impact on energy savings, if the insulation applied externally (2A) or internally (2B) is either thicker or thinner than the $90 \mathrm{~mm}$ of insulation used for the base case, needed to drop the wall's U-value to $0.3 \mathrm{~W} / \mathrm{m} 2 \mathrm{~K}$, as required by Building Regulations. More specifically, results display how the annual energy savings would be affected, if instead of $90 \mathrm{~mm}, 30 \mathrm{~mm}$ and $310 \mathrm{~mm}$ of EPS insulation were added on an uninsulated solid wall of a U-value of 2.1 $\mathrm{W} / \mathrm{m}^{2} \mathrm{~K}$. Figure (a) illustrates the change in annual energy savings as absolute values in $\mathrm{kWh}$ and Figure (b) as percentage increase or decrease.

The carbon savings for each archetype produced from the hypothesis tested and the carbon savings estimated using the RdSAP uninsulated solid wall U-value assumption are illustrated in Figure 7. As illustrated, the energy savings when $310 \mathrm{~mm}$ of EPS insulation was added to a solid wall of a U-value of $0.64 \mathrm{~W} / \mathrm{m}^{2} \mathrm{~K}$ were significantly less than the savings estimated using the RdSAP assumption, with the percentage decrease ranging from $52-57 \%$. 


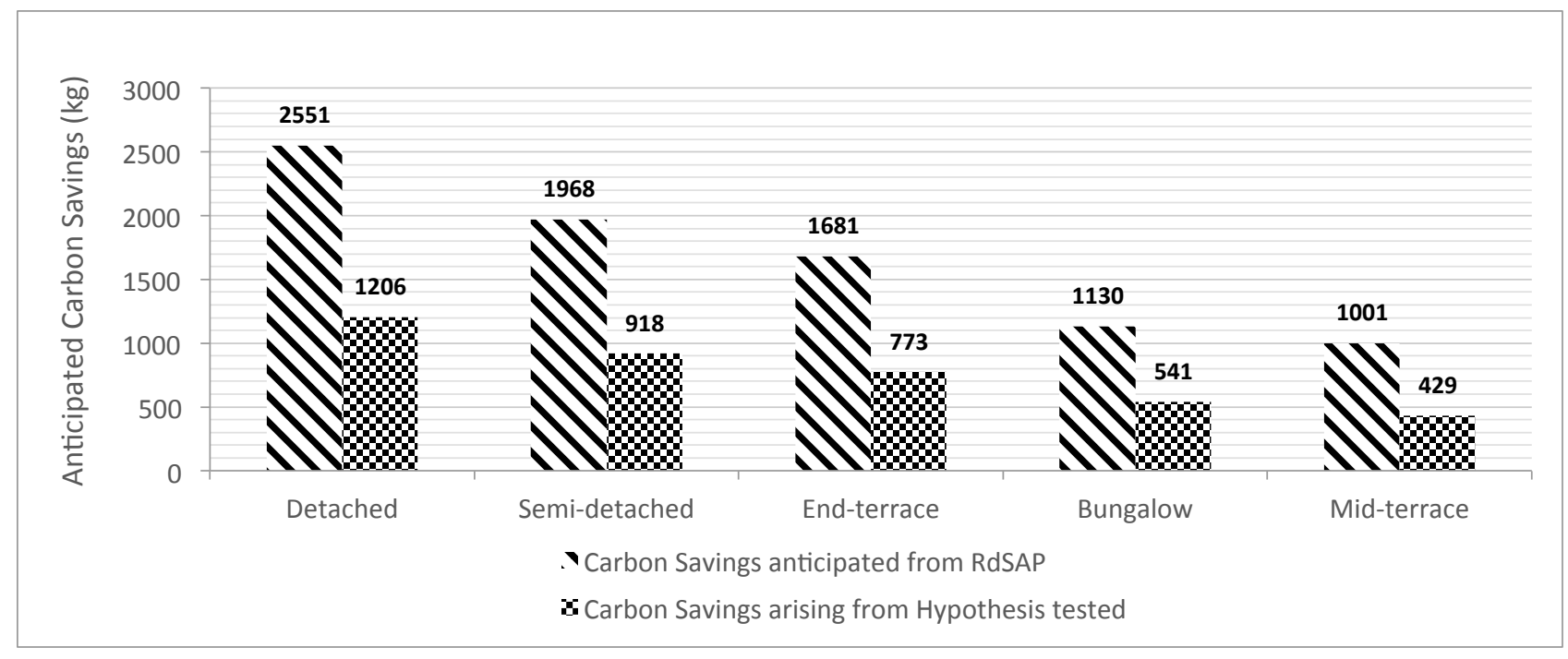

Figure 7. Annual carbon savings expected from all the uninsulated English solid wall properties of the archetypes analysed; for Hypothesis-1 $310 \mathrm{~mm}$ of EPS insulation were added to a solid wall of pre-insulation U-value of 0.64 $\mathrm{W} / \mathrm{m}^{2} \mathrm{~K}$, for Hypothesis-2 $310 \mathrm{~mm}$ of EPS insulation were added to a solid wall of pre-insulation U-value of 1.43 $\mathrm{W} / \mathrm{m}^{2} \mathrm{~K}$ and for the RdSAP anticipated savings $90 \mathrm{~mm}$ of EPS insulation were added to a solid wall of pre-insulation Uvalue of $2.1 \mathrm{~W} / \mathrm{m}^{2} \mathrm{~K}$.

\subsection{Regression analysis}

In Figure 8, the results of the regression analysis carried out to assess the relationship between heating loads and outdoor temperature are displayed. As the U-value of the external wall decreases, the spread of the heating loads also decrease. In Figure 9, the annual space heat demand arising from each U-value is plotted. The gradient of each trendline was characteristic of the energy savings anticipated for each dwelling; the steeper the gradient the more energy savings anticipated for the dwelling. The detached archetype is characterised by a steeper wall U-value - heat load relationship indicating that insulation is more effective as the exposed surface area of dwellings increases. 


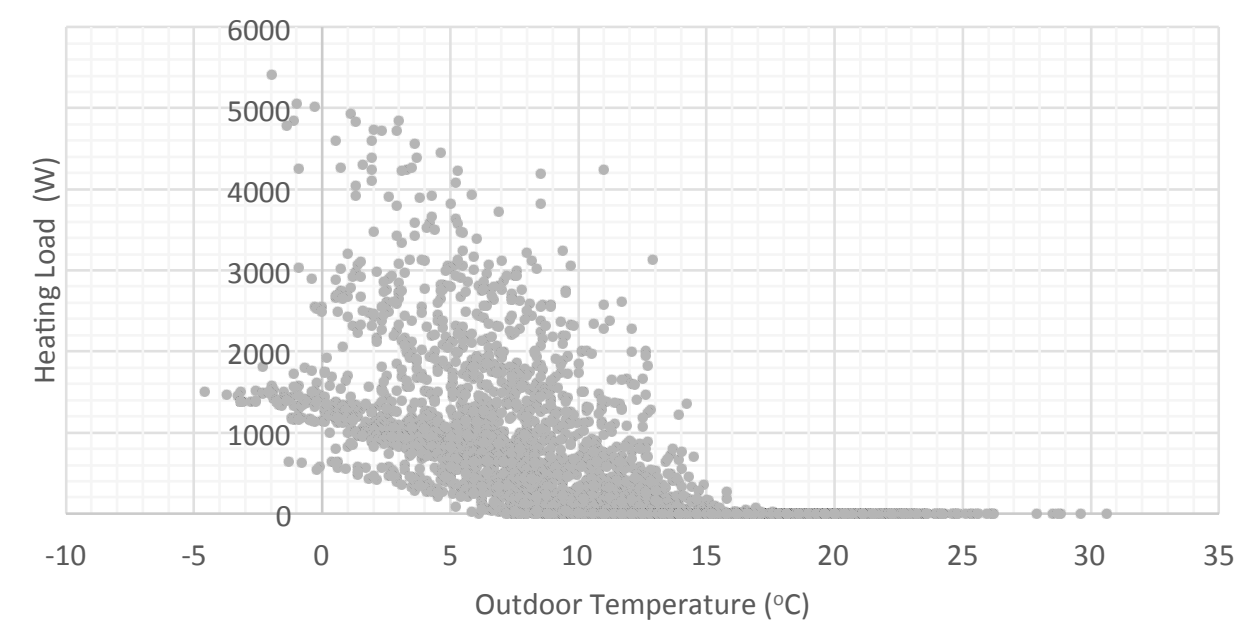

- U-value $=2.1 \mathrm{~W} / \mathrm{m} 2 \mathrm{~K}$

(a)

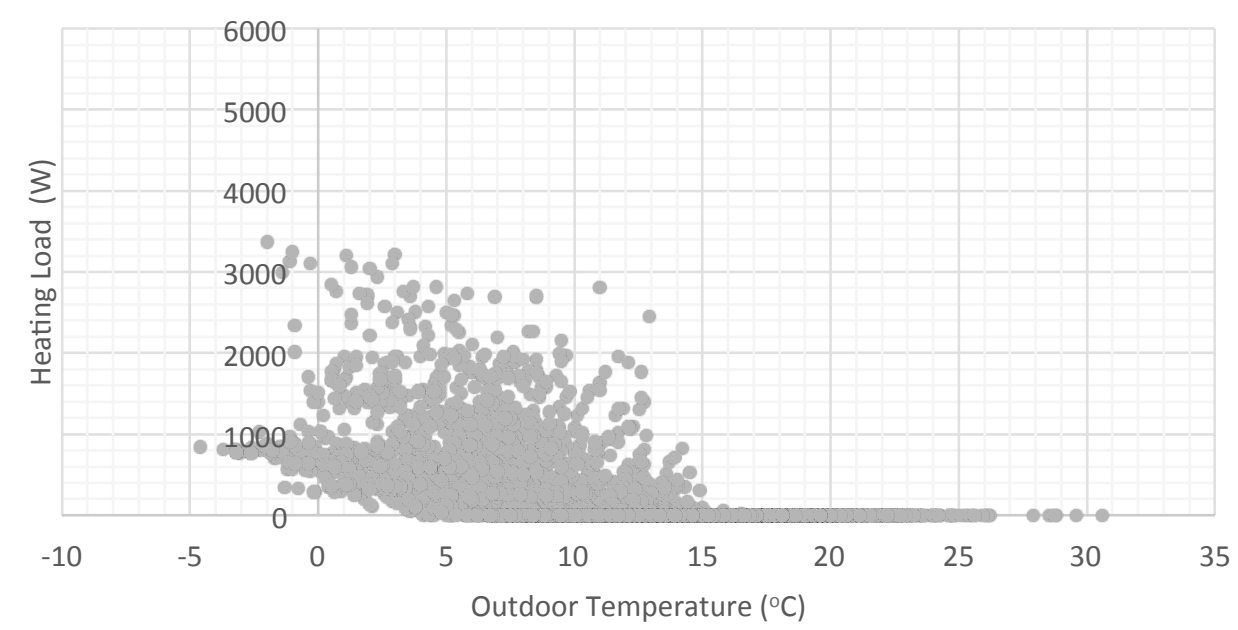

U-value $=0.7 \mathrm{~W} / \mathrm{m} 2 \mathrm{~K}$

(b)

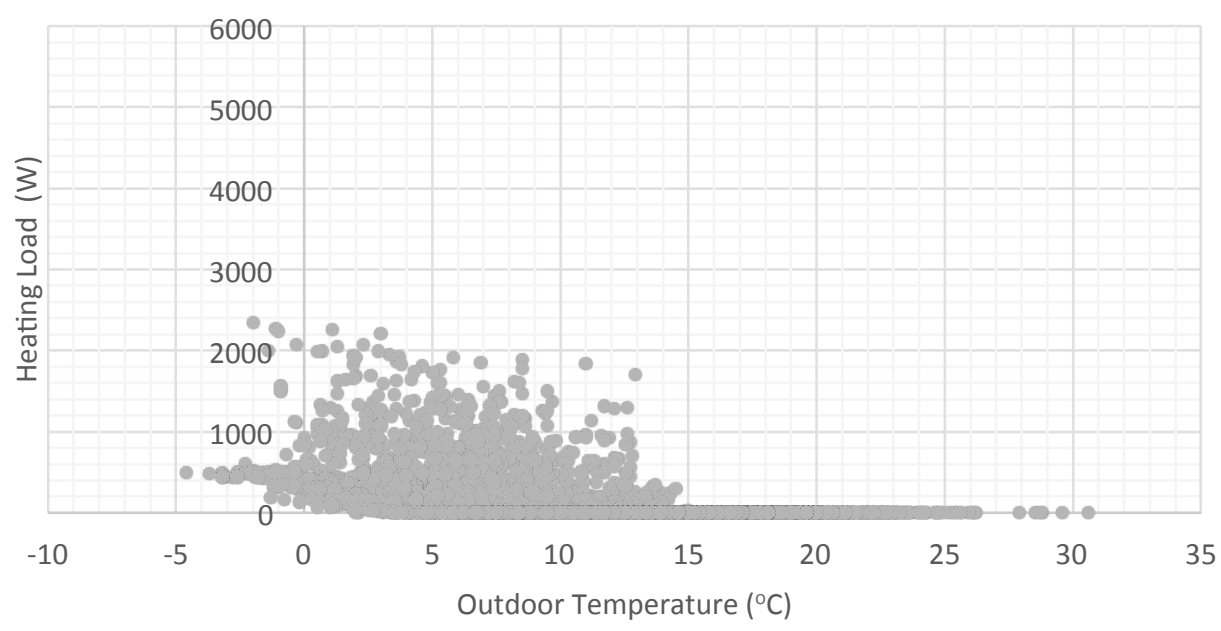

- U-value $=0.1 \mathrm{~W} / \mathrm{m} 2 \mathrm{~K}$

(c)

Figure 8. Regression analysis showing the correlation between the bungalow's indoor heating loads and outdoor temperature during occupancy hours, when applying different U-values to the external walls. 


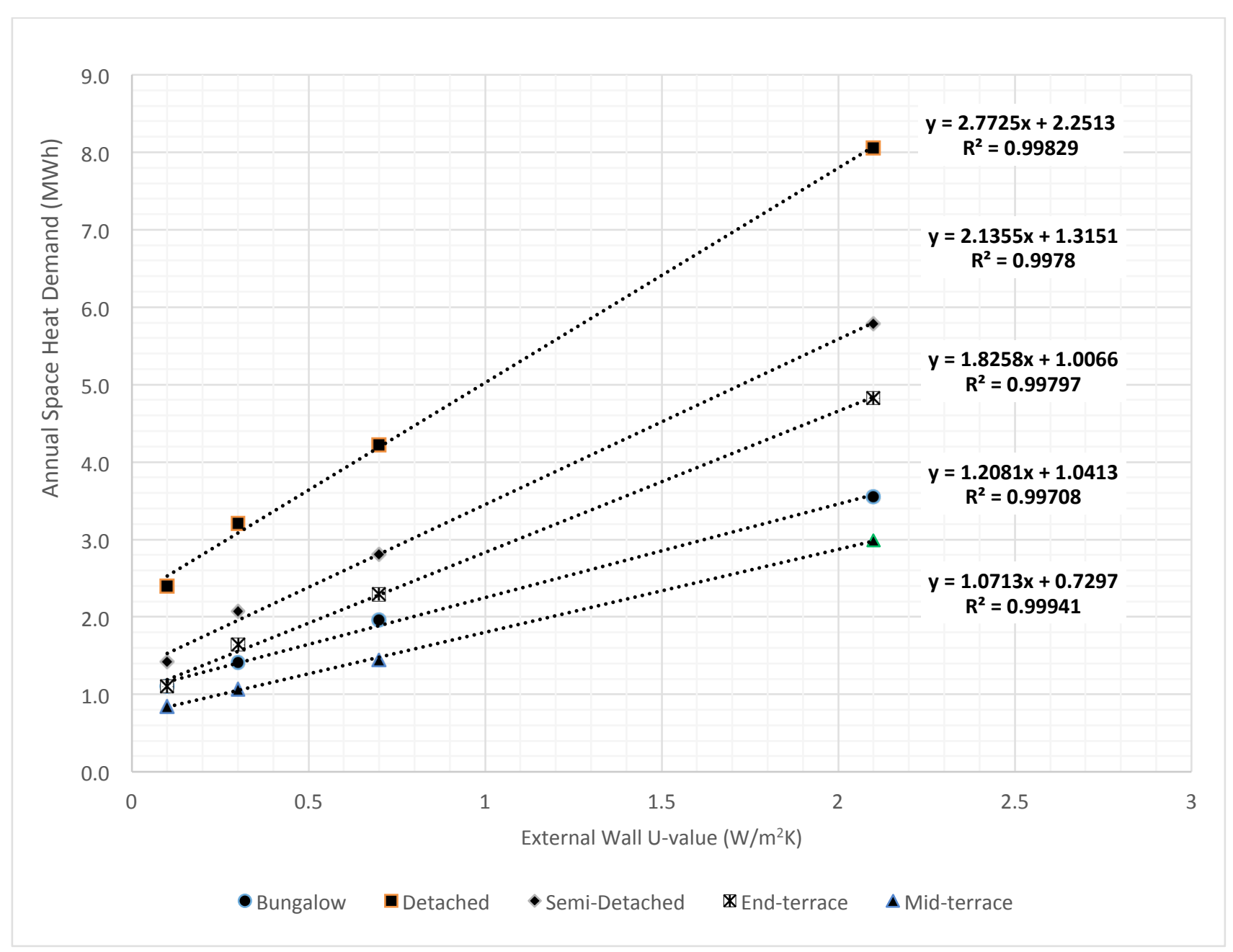

Figure 9. Regression analysis indicating the correlation between the dwellings' annual space heat demand and their external walls U-value.

\section{Discussion}

\subsection{Interpretation of results}

Unsurprisingly, it was indicated that solid wall insulation can appreciably reduce the space heat demand of dwellings verifying findings of previous studies (18). It was also suggested that insulation is more effective as a dwelling's exposed surface area to volume ratio decreases. More specifically it was found that savings per $\mathrm{m}^{2}$ of insulation applied were higher for dwellings with lower exposed surface area to volume ratio such as the mid-terrace dwelling. 
Moreover, the findings of this study indicated that inconsistencies between the actual and the RdSAP assumed solid wall U-value can have a significant impact upon the anticipated energy and carbon savings arising from solid wall insulation. This verifies suggestions from earlier studies (38) that indicated that the overestimation of the actual solid wall U-value would overestimate the dwellings predicted energy consumption that could significantly reduce the carbon savings achievable from solid wall insulation. Additionally, this study went one step further, to reveal the impact that both the insulation thickness and the solid wall U-value can have upon the anticipated energy and carbon savings of different dwelling archetypes, as a result of solid wall insulation. The archetype found to be the most sensitive to variations in the solid wall U-value was the mid-terrace house and the least sensitive the bungalow. This suggested that the sensitivity of each archetype is again dependant on its exposed surface area and volume. More specifically, archetypes with lower exposed surface area to volume ratio were found to be more prone in revealing a performance gap. Nevertheless, for variations in the insulation thickness, the archetype that was found to be the most sensitive was the detached house and the least sensitive the mid-terrace house. In this case it is suggested that the sensitivity of different archetypes to variations in the insulation thickness is influenced by the archetypes' exposed wall area. By looking at the results in Figure 6 and Table 6 it can be seen that as a dwellings exposed wall area increases, its sensitivity to variations in the insulation thickness increase as well. Finally, it was indicated that if the current U-value assumption of $2.1 \mathrm{~W} / \mathrm{m}^{2} \mathrm{~K}$ is indeed an overestimation of the actual value, then the anticipated carbon savings would be much less even if much thicker insulation is applied.

The findings of the regression analysis verified the importance of wall insulation in reducing a dwelling's space heat demand. As the wall's U-value was decreasing, a de-coupling effect was revealed between the indoor and the outdoor environment, whilst the relationship between the space heat demand and wall U-values seems to be getting stronger. These findings are in accordance with previous research, suggesting that the external wall U-value is a key parameter both for reducing energy consumption and the de-coupling of the indoor and outdoor environment via passive means. 


\section{Study implications and future research}

The findings of this study indicated that uncertainties in solid wall U-values could result in a substantial performance gap and, more importantly, to significant under-performance of retrofit measures. More specifically, for solid wall dwellings with U-values of as low as $0.64 \mathrm{~W} / \mathrm{m}^{2} \mathrm{~K}$ savings could be reduced by up to $65 \%$. These findings are in accordance with previous studies (38) which indicated that for solid dwellings with U-values of $1.3 \mathrm{~W} / \mathrm{m}^{2} \mathrm{~K}$ a change in the mean predicted annual heating demand of $16 \%$ could occur. This is crucial as it may have serious repercussions on the Government's carbon reduction goals. Firstly, it can result in significantly lower carbon savings than expected and, secondly, it may affect the uptake of retrofit measures due to doubt about effectiveness of retrofit measures. It is, thus, necessary to undertake extensive research to better understand the thermal behaviour of solid walls and obtain more accurate Uvalues. The high impact of solid wall U-values upon the dwellings' energy performance highlighted in this study suggest that there is need for a more detailed classification of different solid wall archetypes, indicating the thermal characteristics of each wall type. Further work should, therefore, focus on the investigation of solid wall U-values across larger housing samples, representative of the whole UK solid wall housing stock, using a variety of measurement procedures and equipment. Additionally, reviewing and updating current legislation would be required, since the solid wall Uvalues specified in RdSAP may be inaccurate, potentially leading to incorrect estimates of the effectiveness of retrofit measures.

\section{Conclusion}

The purpose of this study was to evaluate the impact of solid wall insulation on dwellings' energy performance and assess the impact of uncertainties in solid wall U-value assumptions on the energy performance gap. The findings of this study confirmed that solid wall insulation can 
appreciably reduce the space heat demand of dwellings and that insulation seems to be more effective as dwellings exposed surface area to volume ratio decreases.

Moreover, the sensitivity analysis indicated that both the insulation thickness and the preinsulation U-value of solid walls have a significant impact upon the anticipated energy savings. The lower U-values indicated for solid walls by previous research can offset the energy savings estimated by RdSAP in such a degree that even thicker insulation cannot fully recover these estimated energy savings. This under-performance of solid wall retrofit needs to be addressed since it will not only result to significantly lower carbon savings but it may also affect the uptake of retrofit measures. In summary, whilst solid walls provide a great opportunity for reducing the UK's carbon emissions, uncertainties in their pre-retrofit thermal performance should be addressed in order for the UK to achieve its housing sector decarbonisation targets.

\section{Declaration of conflicting interests}

The Authors declare that there is no conflict of interest.

\section{Funding}

This research received no specific grant from any funding agency in the public, commercial, or notfor-profit sectors. 


\section{References}

1. IPCC. Climate Change 2014: Impacts, Adaptation, and Vulnerability. Part A: Global and Sectoral Aspects. Contribution of Working Group II to the Fifth Assessment Report of the Intergovernmental Panel on Climate Change. Cambridge University Press, UK, 2014.

2. McMichael, A. J., Woodruff, R. E., \& Hales, S. (2006). Climate change and human health: present and future risks. The Lancet, 367(9513), 859-869.

3. Stern NH. The Economics of Climate Change: The Stern Review. Cambridge University Press; 2007.

4. Parliament, UK. (2008). Climate change act 2008. London, UK.

5. Wright A. What is the relationship between built form and energy use in dwellings? Energy Policy. Elsevier; 2008 Dec;36(12):4544-7.

6. DCLG. English Housing Survey: DA1101 stock profile. London; 2012.

7. Committee on Climate Change. Meeting Carbon Budgets - 2012 Progress Report to Parliament. London, UK; 2012 p. 146.

8. DECC. Department of Energy and Climate Change: Estimation of Home Insulation Levels in Great Britain. 2013. Available from:

https://www.gov.uk/government/uploads/system/uploads/attachment_data/file/240190/statisti cal_release_estimates_home_insulation_levels_gb_july_13.pdf $(2013$, accessed 10 June 2014).

9. NIA. National Insulation Association: Heat loss through solid walls. Available from: http://www.nia-uk.org/householder/index.php?page=did-you-know-facts (2014, accessed 29 June 2014).

10. DCLG. English Housing Survey (EHS). London; 2011.

11. The Engineering Toolbox. Density of Bricks. Available from:

http://www.engineeringtoolbox.com/bricks-density-d_1777.html (2014, accessed 01 July 2014).

12. Biddulph $\mathrm{P}$, Gori V, Elwell CA, et al. Inferring the thermal resistance and effective thermal mass of a wall using frequent temperature and heat flux measurements. Energy and Buildings. Elsevier B.V.; 2014;78:10-6.

13. DECC. The Government's Standard Assessment Procedure (SAP) for Energy Rating of Dwellings. 2009.

14. CSE. Centre for Sustainable Energy: Analysis of hard-to-treat housing in England. Report, November 2011.

15. DCLG. The Building Regulations 2010 (1LB): Conservation of fuel and power in existing dwellings. 2011. 
16. Porritt SM, Cropper PC, Shao L, et al. Ranking of interventions to reduce dwelling overheating during heat waves. Energy Build. Elsevier B.V.; 2012 Dec;55:16-27.

17. Energy Saving Trust. Choosing internal wall insulation. Available from: http://www.energysavingtrust.org.uk/Insulation/Solid-wall-insulation/Choosing-internalwall-insulation (2014, accessed 04 July 2014).

18. TSB. Technology Strategy Board: Retrofit for the Future Analysis Report. Report, 2013.

19. Zero Carbon Hub. Closing the gap between design and as-built performance performance. Report, March 2014.

20. Wingfield J, Bell M, Miles-Shenton D, et al. Lessons from Stamford Brook: Understanding the Gap between Designed and Real Performance. Report, UK, November 2008;

21. Wingfield J, Bell M, Miles-Shenton D, et al. Elm Tree Mews Field Trial - Evaluation and Monitoring of Dwellings Performance. Report, UK, January 2011;

22. Miles-Shenton D, Wingfield J, Sutton R, et al. Temple Avenue project Part 1- Energy efficient renovation of an existing dwelling: Evaluation of Design \& Construction and Measurement of Fabric Performance of new built dwellings. Report, UK, May 2010;

23. Wingfield J, Miles-Shenton D, Bell M. Evaluation of the Party Wall Thermal Bypass in Masonry Dwellings. Report, UK, May 2009;

24. Wingfield J, Bell M, Miles-Shenton. Investigations of the Party Wall Thermal Bypass in Timber Frame Dwellings. Report, UK, June 2010;

25. Wilde P De, Jones R. The building energy performance gap: up close and personal. CIBSE. Dublin, Ireland. Report, April 2014;

26. BRE. Solid wall heat losses and the potential for energy saving. Report, UK, May 2014.

27. Centre for Low Carbon Futures. The Retrofit Challenge: Delivering Low Carbon buildings. Report, UK, November 2011.

28. Stevens G, Bradford J. Do U-value insulation? England's field trial of solid wall insulation. 2009. In: ECEEE 2013 Summer Study: Rethink, renew, restart . Paper no. 5A-338-13.

29. DECC. The Government's Standard Assessment Procedure (SAP) for Energy Rating of Dwellings. 2012.

30. Rye C, Scott C. The SPAB research report 1: U-value report. Report, UK, November 2012.

31. Baker P, Rhee-Duverne S. Research Into The Thermal Performance Of Traditional Brick Walls: In-situ U-values of solid brick walls and Thermal conductivities of three traditional bricks. Report, UK, 2013.

32. Gori V, Biddulph P, Elwell CA, et al. Seasonal factors influencing the estimation of the Uvalue of a wall. In: 2nd Building Simulation and Optimization (BSO14) conference, UK, June 2014. 
33. Sustainable Traditional Buildings Alliance. Responsible Retrofit of Traditional Buildings: A Report on Existing Research and Guidance with Recommendations. Report, UK, September 2012.

34. Anderson B. BR 443: Conventions for U-valuecalculations. Watford: BRE Press; 2006.

35. British Standards Institute. BS EN ISO 6946: Building Components and Building ElementsThermal resistance and thermal transmittance. 1997.

36. Trinick J, Elliot E, Green M, et al. Communities and Local Government (CLG): Research into Compliance with Part L of the Building Regulations for New Homes - Phase 2 Main Report, Energy Efficiency Partnership for Homes. Report, UK, 2009.

37. Carbon Trust. Closing the gap. Report, UK, July 2011.

38. Li FGN, Smith a. ZP, Biddulph P, Hamilton IG, et al. Solid-wall U-values: heat flux measurements compared with standard assumptions. Building Research \& Information. 2014 Oct 16;43(2):238-52.

39. Henderson J, Hart J. BREDEM 2012, A technical description of the BRE Domestic Energy Model, Version 1.1. 2013;

40. EDSL. EDSL Tas: Validation. Available from: http://www.edsl.net/main/software/Validation.aspx (2014, accessed 20 June 2014).

41. Oikonomou E, Mavrogianni A, Raslan R, et al. English Archetypes: Developing a domestic model for building performance calculations. To be submitted. 2015;

42. DECC. The Green Deal and Energy Company Obligation Consultation Document. Report, UK, November 2011.

43. Chown I. Houses and flats. Metric handbook: planning and design data. 3rd ed. Littlefield D, editor. Oxford, UK; 1970.

44. Bruckmann H, Lewis D. New housing in Great Britain. 1st ed. London, UK: Alec Tiranti Ltd; 1960.

45. Jensen F. The English semi-detached house. Cambridgeshire: Ovolo Publishing Ltd; 2007.

46. Muthesius S. The English Terraced house: layout and construction. New Haven and London: Yale University Press; 1982.

47. Woodman E, Greeves E. Home/away: five British architects build housing in Europe: the development of housing in Britain. Venice: British Council; 2008.

48. Chapman PF. A geometrical model of dwellings for use in simple energy calculations. Energy Build. 1994 Jan;21(2):83-91.

49. Stephen, R. (2000). Airtightness in UK dwellings. BRE. Watford; 2000.

50. Sherman MH. Estimation of infiltration from leakage and climate indicators. Energy Build. $1987 ; 10(1),: 81-6$. 
51. Jablite. Jablite EPS Classic Datasheet. Available from:

http://www.jablite.co.uk/site/datasheets/3/3.pdf (2014, accessed 06 July 2014).

52. CIBSE. CIBSE Weather Data Sets. Available from:

http://www.cibse.org/Knowledge/CIBSE-other-publications/CIBSE-Weather-Data-Current,Future,-Combined-DSYs, (2014, accessed 20 July 2014).

53. Oikonomou, E., Davies, M., Mavrogianni, A., et al. (2012). Modelling the relative importance of the urban heat island and the thermal quality of dwellings for overheating in London. Building and Environment, 57, 223-238.

54. CIBSE. Guide A - Environmental design. 7th ed. Chartered Institution of Building Services Engineers, editor. 2006.

55. Lader D, Short S, Gershuny J. Office for National Statistics. The Time Use Survey, 2005: How We Spend Our Time. Report, London, UK; July 2006.

56. Yao, R., \& Steemers, K. (2005). A method of formulating energy load profile for domestic buildings in the UK. Energy and Buildings, 37(6), 663-671.

57. CIBSE. Guide F: Energy efficiency in buildings. The Chartered Institution of Building Services Engineers, editor. London, UK; 2004.

58. Firth, S., Lomas, K., Wright, A., \& Wall, R. (2008). Identifying trends in the use of domestic appliances from household electricity consumption measurements. Energy and Buildings, 40(5), 926-936.

59. Alaskan ABS. Average power consumption of household appliances. Available from: http://www.absak.com/library/power-consumption-table (2008, accessed 10 July 2014).

60. US DoE. Energy savers: Estimating appliance and home electronic energy use. Available from: http://energy.gov/energysaver/articles/estimating-appliance-and-home-electronicenergy-use (2009, accessed 9 July 2014).

61. Hendron R. US DoE: Building America research benchmark definition. Report, U.S, January 2007.

62. Lomas, K. J., \& Eppel, H. (1992). Sensitivity analysis techniques for building thermal simulation programs. Energy and buildings, 19(1), 21-44.

63. Kingspan Insulation. Passivhaus Buildings: Case Studies. Report, UK, March 2015. 